\begin{tabular}{|c|l|}
\hline Title & Crustal structure and evolution of the outer Møre Margin, NE A tlantic \\
\hline Author(s) & Mjelde, R.; Raum, T.; Kandilarov, A.; Murai, Y.; T akanami, T. \\
\hline Citation & $\begin{array}{l}\text { Tectonophysics, 468(1-4), 224.243 } \\
\text { https://doi.org/10.1016/.tecto.2008.06.003 }\end{array}$ \\
\hline Issue Date & 2009-04_01 \\
\hline Doc URL & http://hdl.handle.net/2115/38624 \\
\hline Type & article (author version) \\
\hline File Information & 468-1-4_p224243.pdf \\
\hline
\end{tabular}

Instructions for use 


\section{Crustal structure and evolution of the outer Møre Margin, NE}

\section{Atlantic}

R. Mjelde ${ }^{1}$, T.Raum ${ }^{1}$, A. Kandilarov ${ }^{1}$, Y.Murai ${ }^{2}$, T. Takanami ${ }^{2}$

${ }^{1}$ Department of Earth Science, University of Bergen, Allegt. 41, 5007 Bergen, Norway (e-mail corresponding author: Rolf.Mjelde@geo.uib.no)

${ }^{2}$ Institute for Seismology and Volcanology, Hokkaido University, Sapporo 060, Japan

\section{Abstract:}

Five regional Ocean Bottom Seismic profiles from the northwestern part of the Møre Margin, NE Atlantic, have been modeled with regard to crustal structure, and the interpretations have been supported by the use of multi-channel seismic and potential field data. The chi-squared values (uncertainty) for the studied profiles are generally in the range $1-3$, and the uncertainty in the Moho depth is estimated to $+/-1 \mathrm{~km}$. The Continent-Ocean-Transition is found to be relatively sharp (10-40 km wide) expressing a change in physical properties corresponding to felsic continental crust along the landward part of the marginal high $\left(\mathrm{V}_{\mathrm{p}}=6.2-6.5 \mathrm{~km} / \mathrm{s}\right)$, and thick, mafic oceanic crust further northwestwards. The Early Eocene breakup was associated with excessive magmatism, and the models document direct continuity between this magmatism and a lower crustal high-velocity layer in the Møre Basin $\left(\mathrm{V}_{\mathrm{p}}=7.1-7.3\right.$ $\mathrm{km} / \mathrm{s}$ ), suggesting a genetic link. The Jan Mayen Lineament is observed across the entire study area as northeastward termination of the lower crustal body, as well as structuring in the top of the crystalline basement and the Moho. We present a 
speculative model involving lower crustal bodies of eclogites ( $\mathrm{Vp}>8 \mathrm{~km} / \mathrm{s})$ inferred in the easternmost part of the Møre Basin linking the Jan Mayen Lineament to the post-Caledonian Nordfjord-Sogn Detachment.

Keywords: Møre Margin, Jan Mayen Lineament, lower crustal high-velocity body, eclogites, OBS data.

\section{Introduction}

The central part of the mid-Norwegian Margin, the Vøring Marin, is well studied through integrated geological and geophysical efforts, including commercial and academic drillholes (e.g., Eldholm et al., 1989; Fig. 1). The Møre Margin, located to the south of the Vøring Margin, has received significantly less attention. The present paper addresses the northern part of the outer Møre Margin, with main focus on variations in magmatism and tectonic style along strike and the role of pre-existing structures in margin development.

After the Caledonian Orogeny, the area experienced episodic extension during c. 350 Myr, culminating with continental breakup around magnetic anomaly 24B (c. 55 Ma; e.g., Eldholm et al., 1989). The rifting activity can be grouped into three broad rifting events, the Carboniferous-Triassic, the Middle Jurassic-earliest Cretaceous, and the latest Cretaceous-Paleocene episodes (Brekke et al., 2001). The post-opening evolution reflects the sedimentation on a subsiding margin, overprinted by two main phases of compression associated with the formation of intra-basinal domes, dated to latest Eocene/earliest Oligocene and late-Middle Miocene (e.g., Blystad et al., 1995). The onset of glaciations at c. 2.7 Ma led to deep mainland erosion and deposition of 
large sediment volumes on the adjacent shelf and basins (e.g., Riis and Fjeldskaar, 1992).

The outer part of the Møre and Vøring Margins are offset by c. $200 \mathrm{~km}$ along the Jan Mayen Fracture Zone (JMFZ). This represents the only major fracture zone between the Faroe-Iceland Ridge and the Senja FZ, marking the SE boundary of the Barents Sea (Mjelde et al., 2008c). The postulated landward (continental) continuation of the JMFZ, the Jan Mayen Lineament (JML) is generally interpreted as reactivated Proterozoic structuring (Doré et al., 1997).

The Møre Margin is bounded to the NE by the JML, to the NW by the Early Eocene oceanic crust, and the SW-NE trending Møre Trøndelag Fault Complex (MTFC) marks its southeastern termination. The Møre Margin`s southwestern boundary remains to be defined, and we propose the Faroe-Iceland Ridge (Faroe FZ and Claire Lineament; Kimbell et al., 2005; Mjelde et al., 2008c) with this regard. The Scoresby-Bergen Lineament, as postulated by Brekke et al. (2001), might represent an alternative definition.

The Møre Margin is divided into the Møre Basin, which documents the postCaledonian extension, and the Møre Marginal High dominated by Early Tertiary magmatism. The Møre Marginal High is bounded southeastwards by the FaroeShetland Escarpment (FSE). On the Vøring Margin to the north, zones of Caledonian extension (detachments) have been mapped from the mainland and across the Vøring Basin almost to the Continent-Ocean-Transition (COT; Osmundsen et al., 2002; Ebbing et al., 2006; Mjelde et al., 2008a). For example, the boundary between the Vøring and Lofoten Margins, the Bivrost Lineament, represents a major change in crustal structure observed in multi-channel seismic (MCS), Ocean Bottom Seismic (OBS) and potential field data. However, it does not continue westward as a 
prominent oceanic fracture zone (Olesen et al., 2007). The opposite it the case for the JMFZ-JML system; the JML is not observed as a clear lineament in MCS or potential field data. The JML seems to delineate an area with dominantly SW-NE trending structures in the Møre Basin and more N-S trending structures to the north. In addition, the area may represent a transfer zone from extension dominantly related to westward dipping faults in the Møre Basin and eastward-dipping faults in the Vøring Basin (Osmundsen et al., 2002).

In order to identify and characterize the postulated JML, a comprehensive set of OBS data was acquired along the outer Møre Margin (Fig. 1). The wide-angle OBS methodology was chosen, since it has documented the existence of crustal scale lineaments within the Vøring Basin (Mjelde et al., 2003a). Furthermore, the method has provided a relatively detailed map of a lower crustal high-velocity body (LCB; 7.2-7.6 km/s) in the Vøring Basin, and documented links between its distribution and location of crustal scale lineaments. The physical properties of the LCB correspond to mafic rocks (Mjelde et al., 2008a), and the body has been interpreted as Caledonian (e.g., Gernigon et al., 2004; Ebbing et al., 2006) or Early Tertiary age (e.g., Mjelde et al., 2008a). The LCB has also been observed in the Møre Basin along one Expanded Spread Profile (ESP; Olafsson et al., 1992) and one OBS profile (Raum et al., 2000; Mjelde et al., 2007b). In the southern Vøring Basin the LCB is replaced by a body with upper mantle velocities (> $8 \mathrm{~km} / \mathrm{s}$ ), interpreted as lower crustal eclogites (Raum et al., 2006). The same observation and interpretation was made for the two wideangle profiles in the easternmost part of the Møre Basin (Olafsson et al., 1992; Mjelde et al., 2007b). A secondary aim with the OBS survey along the outer Møre Margin was to map the LCB, and its possible link to other high-velocity terrains and the JML. 
The present paper describes the modeling of the OBS data, supported by gravity modeling, and discusses the model`s geological implications.

\section{Data acquisition and processing}

The data acquisition was carried out in 1999, by use of R/V Håkon Mosby (University of Bergen, UoB), as a standard, regional OBS-survey (e.g., Mjelde et al., 1997). The air-gun source consisted of four Bolt $1500 \mathrm{C}$ air-guns with a total volume of $4800 \mathrm{in}^{3}$, fired every $200 \mathrm{~m}$. The shot-point position was controlled by a Differential Global Positioning System (DGPS). OBSs belonging to Hokkaido University were used as receivers. These instruments contained digital recorders with 12 days storage capacity, and $4.5 \mathrm{~Hz}$, gimbal-mounted, geophones. A total of 38 OBSs were deployed, and the 7 instruments located at intersections between lines recorded data shot along both crossing profiles. Two OBSs were lost; 12 and 19 deployed along 2-99, and OBS 9 along 1-99 did not contain useful data. The same applied for OBS 7 for the shooting along 4-99. The survey thus resulted in a total of 41 OBS receiver gathers.

The processing was limited to band-pass filtering; 5-12 Hz and 5-14 Hz for the vertical and horizontal components, respectively. The data are plotted with an Automatic Gain Control (AGC) window of 4s, and the time-scale has been reduced with a velocity of $8 \mathrm{~km} / \mathrm{s}$. Additional processing involving FK filtering and deconvolution was attempted with limited success, as is often the case in complex tectono-magmatic provinces (e.g., Mjelde et al., 1997). Marine gravity data were acquired along all profiles with a Lacoste \& Romberg gravity meter, and the data have been subject to standard processing. 


\section{Modeling procedure and uncertainties}

All OBS profiles were acquired along MCS lines gathered earlier (industrial, nonreleased data). The first step in the data analysis consisted of interpreting the MCS data, which provided detailed images from the seafloor to the top of the Early Eocene basalt in the northwestern part of the area, and down to the base Cretaceous discontinuity in the Møre Basin. The dating of interfaces is in agreement with the Norwegian Petroleum Directorate (NPD) database. The base of the basalt and base Cretaceous were interpreted along parts of the marginal high, but it must be underlined that the interpretation is uncertain here. The interpreted seismic sections were subsequently depth-converted, using velocities derived from the neighbouring OBS profile 8-96 (Fig. 1; Raum et al., 2002; Mjelde et al., 2007b).

P-waves interpreted from the OBS vertical components were then modeled by use of the inversion/ray-tracing software developed by Zelt and Smith (1992). The modeling was done in a layer-stripping way from the seafloor and downwards (Zelt and Forsyth, 1994), minimizing the difference between interpreted and calculated travel-time curves (critical refractions and wide-angle reflections). The modeling implied slight adjustment of P-wave velocities and depth to interfaces. In order to model later arrivals, interfaces were added below the deepest interface derived from the MCS interpretation and modeled following the same procedure. The resulting model consists of P-wave velocities and velocity-discontinuities (interfaces) as function of depth. All layers express a slight velocity increase with depth, and lateral variations have also been modeled. Wide-angle reflections observed on 1-2 neighbouring instruments have been including as short segments within layers 
(floating reflectors). Such reflectors are generally attributed to intrusions and/or faults (e.g., Mjelde et al., 1997). Figs. 2-5 show some examples of interpreted vertical component data, fit between the interpreted and calculated travel-time curves and ray paths through the models. The P-wave models are presented in Figs. 6a-10a.

The P-wave models were then used as a basis for gravity modeling. For this purpose, the British Geological Survey Interactive 2D modeling software was used. Starting densities were derived from standard density-velocity relationships (Ludwig et al., 1970), and slight modifications of interfaces and densities were made during the modeling. The changes were implemented in the P-wave models, and gravity and Pwave modeling were then performed iteratively until both datasets matched the observations. The gravity models are shown in Figs. 6b-10b.

The P-wave models were then used as basis for modeling the S-waves interpreted from the horizontal components, rotated in-line by use of the polarization of the direct water-arrival. During the ray-tracing modeling the interfaces were kept constant, and P-to-S conversion interfaces and S-wave velocities, expressed as the Vp/Vs-ratio, were derived for successively deeper layers (Figs. 6a-10a). The modeling included waves converted on the way down, PSS arrivals, and up, PPS arrivals, propagating with apparent S-wave and P-wave velocities, respectively (Mjelde et al., 2002). Figs. 11-12 show two examples of interpreted horizontal component data, fit between the interpreted and calculated S-wave travel-time curves and ray paths through the models.

The uncertainty of the modeling is commonly expressed as the chi-squared value, weighing the mismatch between observed and calculated arrival times to the estimated uncertainty of the interpretation, and the RMS misfit values. During the modeling of the profiles discussed in this paper the uncertainty of travel-time curves 
has generally been estimated to $50 \mathrm{~ms}$, but for some arrivals the uncertainty is higher, up to $200 \mathrm{~ms}$. Assuming the same uncertainties in a similar geological setting, Mjelde et al. (2005), showed that chi-squared values $<5$ signifies a reasonable fit. Fig. 13 shows that the chi-squared values for the studied profiles are generally in the range 13, and Tab I shows that the RMS misfit values are low (less than 0.1 ). The uncertainty is significantly higher for the shallowest layers, since few travel-time curves overlap between different OBSs here. However, this part of the model is well constrained from the MCS data.

Such uncertainty plots should be interpreted with care, as the chi-squared can be reduced by increasing the user-defined uncertainty of travel-time branches. It is also important to underline that such uncertainty estimates only quantifies the misfit between the interpretation and calculated curves. The main source of uncertainty is inherent in the interpretation itself (e.g., cycle-skipping), which, as for interpretation of MCS data, cannot be quantified. Plotting the ray-coverage represents a more useful manner to evaluate the uncertainty (Figs. 14, 15). These plots show that the COT and LCB are well covered, but that the uncertainty increases towards the ends of the profiles. Those parts are constrained by the gravity modeling only. Except for the poorly constrained parts of the profiles closer than $30 \mathrm{~km}$ to end points, we estimate the uncertainty in P-wave velocity to $+/-0.1 \mathrm{~km} / \mathrm{s}$, which corresponds to $+/-1 \mathrm{~km}$ uncertainty in depth to the LCB and Moho. The uncertainty for the Vp/Vs-ratio is estimated to $+/-0.05$. These estimates incorporate both the objective estimates of the misfit between observed and calculated curves, and the subjective estimates of uncertainties related to the interpretation of the data. The geological interpretations as presented in this paper are well constrained, primarily derived from averaged and 
integrated use of MCS, OBS P-waves, OBS S-waves, and supported by gravity and magnetic data.

\section{Modeling results}

\subsection{Post-breakup sediments}

The thickness of the layer of post-breakup sediments is larger towards the northeast and southwest, with a maximum of $3 \mathrm{~km}$ estimated for profile 3-99. The layer is thinnest at the marginal high along 5-99, where the Early Eocene basalt locally is observed to outcrop at the seafloor. The large variations in thickness can mainly be attributed to the recent Storegga Slide, covering most of the study area (8100 yrs BP; Haflidason et al., 2004). The P-wave velocities are modeled to increase from a minimum of $1.75 \mathrm{~km} / \mathrm{s}$ below the seafloor to a maximum of $2.45 \mathrm{~km} / \mathrm{s}$ above the basalt. The corresponding densities are 1.8 and $2.35 \mathrm{~g} / \mathrm{cm}^{3}$, respectively, and the $\mathrm{Vp} /$ Vs-ratios are modeled to decrease from a minimum of 4.5 below the seafloor to a maximum of 2.2 above the basalt. These typical variations with depth are mainly due to increased compaction and reduction of porosity (Chung et al., 1990; Mjelde et al., 2003b).

\subsection{Lava flows / oceanic layer 2}

The top of the Early Eocene basaltic layer is well constrained from MCS data, but its base is interpreted with large uncertainty. From the landward termination in the Møre Basin (Fig. 1), the thickness of the Early Eocene basaltic layer is interpreted to 
increase relatively uniformly northwestwards, with a local maximum of $2.8 \mathrm{~km}$ along the northwestern side of the marginal high (5-99). Here, a diffuse pattern of Seaward Dipping Reflectors, characteristic of volcanic margin basalts (Eldholm et al., 1989), can be inferred from the MCS data. The layer is thus interpreted as a continental flood-basalt complex gradually changing into oceanic layer 2 oceanwards (Mjelde et al., 2005). Oceanic layer 2 along 1-99 and 2-99 is divided into layer 2A and 2B, generally interpreted as extrusive pillow lavas and part of the intrusive dike complex, respectively (e.g., White et al., 1992). The base of the basalt, as interpreted from the MSC data, has not been modified following the OBS modeling. The minimum Pwave velocity near the top of the basalt is estimated to $3.65 \mathrm{~km} / \mathrm{s}$, and the maximum velocity near the base of layer $2 \mathrm{~B}$ is $6.0 \mathrm{~km} / \mathrm{s}$. The corresponding densities are 2.45 and $2.75 \mathrm{~g} / \mathrm{cm}^{3}$, and the average $\mathrm{Vp} / \mathrm{Vs}$-ratio is modeled to 1.85 , characteristic for mafic (basaltic) rocks (Holbrook et al., 1992).

\subsection{Pre-breakup sedimentary section}

A 100-300-m-thick Paleocene sedimentary sequence, unresolvable in the OBS data, has been included beneath the landward part of the basalt in all profiles except 2-99. The thickness of the Cretaceous sedimentary package decreases relatively uniformly from a maximum of $8 \mathrm{~km}$ in the basin area to below the limit of resolution around the FSE. The P-wave velocities increase with depth from $2.5-2.9 \mathrm{~km} / \mathrm{s}$ near the top of the sequence to 4.3-5.1 km/s above the Base Cretaceous unconformity. The densities follow a similar increase with depth from c. 2.4 to $2.7 \mathrm{~g} / \mathrm{cm}^{3}$. The average Vp/Vs-ratio demonstrates a decrease with depth from c. 1.9 to 1.7 , which is attributed to reduction in porosity (Chung et al., 1990). The measured Vp/Vs-ratios indicate mixed 
sand/shale composition, with absence of thick sandy layers (Domenico, 1984; Mjelde et al., 2003b). In the northeastern part of the area, two high-velocity arrivals are inferred from within the deeper part of the Cretaceous unit in profiles 2-99, 3-99 and 5-99. Such arrivals, generally interpreted as Early Tertiary basaltic sills, have been modeled throughout the Vøring Basin (e.g., Mjelde et al., 1997). In the study area, the P-wave velocity is estimated to c. $4.8 \mathrm{~km} / \mathrm{s}$ in the shallowest sill, and c. $5.7 \mathrm{~km} / \mathrm{s}$ in the deepest. The estimates of velocities and thicknesses of the sills are uncertain.

The pre-Cretaceous layer, which base cannot be inferred from the MCS data, expresses large variations in thickness in the area. The thickness is measured to a maximum of $6.5 \mathrm{~km}$ in the southern part of the survey area (1-99), from the marginal high and landwards. In the central part the thickness varies from 1-3 km, and a local maximum of $5 \mathrm{~km}$ is inferred in the northeasternmost part of 4-99. The southern area of increased thickness corresponds to an area where a reflector at 10-11 km depth was inferred from the MCS-data. With reference to regional mapping (e.g., Brekke et al., 2001), we interpret the reflector as early Triassic, implying the presence of 2-3 km of Paleozoic sequences here. The P-wave velocities in the pre-Cretaceous section are modeled to increase with depth from $4.5-5.0 \mathrm{~km} / \mathrm{s}$ near the top to $5.1-5.6 \mathrm{~km} / \mathrm{s}$ above the crystalline basement. The corresponding values for densities are c. $2.5-2.75 \mathrm{~g} / \mathrm{cm}^{3}$, and the average $\mathrm{Vp} / \mathrm{Vs}$-ratio is modeled to 1.7 , conformable with mixed sand/shale composition (Domenico, 1984).

\subsection{Continental, crystalline crust}

A P-wave arrival with velocity measured to c. $6.2 \mathrm{~km} / \mathrm{s}$ is interpreted as the top of the continental, crystalline basement, in agreement with earlier studies from the 
Vøring Basin (e.g., Mjelde et al., 1997). The thickness of the uppermost crystalline layer varies between 3 and $11 \mathrm{~km}$, with the thickest portion corresponding to the marginal high in the central part of the study area. The P-wave velocity is modeled to increase with depth within the layer from c. 6.2 to $6.5 \mathrm{~km} / \mathrm{s}$. The average density is modeled to $2.85 \mathrm{~g} / \mathrm{cm}^{3}$, and the $\mathrm{Vp} / \mathrm{Vs}$-ratio is estimated to 1.7 , corresponding to felsic (granitic) basement (e.g., Holbrook et al., 1992).

The upper crystalline crust is underlain by a lower-crustal high-velocity layer, with P-wave velocity averaging $7.1 \mathrm{~km} / \mathrm{s}$ near the top and $7.3 \mathrm{~km} / \mathrm{s}$ at the base. The thickness of the body varies from 2 to $5 \mathrm{~km}$, and it terminates in the northeastern part of the study area. The average density of the layer is modeled to $3.1 \mathrm{~g} / \mathrm{cm}^{3}$, and the $\mathrm{Vp} / \mathrm{Vs}$-ratio is calculated to 1.85 , corresponding to mafic (gabbroic) rocks (Holbrook et al., 1992).

\subsection{Oceanic layer 3 and Moho}

The transition from continental to oceanic crust generally corresponds to a marked increase in P-wave velocity (e.g., Mjelde et al., 2005). In the study area, this oceanward increase is clearly seen in the layer modeled as the deepest sedimentary layer in the Møre Basin and oceanic layer 3A northwest of the marginal high (upper part of magma chamber; White et al., 1992). The transition is particularly clear along 1-99 and 5-99, where an oceanward increase in P-wave velocity from 5.0-5.1 to 6.2$6.5 \mathrm{~km} / \mathrm{s}$ is observed near the top of the layer over less than $10 \mathrm{~km}$ distance. The expected corresponding density increase is not obvious for 1-99, but 2-99 and 5-99 express clear oceanward increase in modeled densities from 2.6 to $2.8 \mathrm{~g} / \mathrm{cm}^{3}$ and 2.4 
to $2.9 \mathrm{~g} / \mathrm{cm}^{3}$, respectively. A lateral increase in the Vp/Vs-ratio from c. 1.7 (felsic continental) to 1.85 (gabbroic oceanic) is inferred for all profiles.

A more gradual oceanward P-wave increase from c. $6.2 \mathrm{~km} / \mathrm{s}$ to c. $6.6-6.9 \mathrm{~km} / \mathrm{s}$ is observed in the upper crystalline layer. This lateral difference is not resolvable in the gravity and S-wave data, as the layer is pinched out westwards. The lower crustal high-velocity layer continues oceanward into oceanic layer 3B (lower part of magma chamber) without any observable modification of physical properties.

The depth to the Moho is estimated at $11 \mathrm{~km}$ along the northwestern part of 1-99, corresponding to a magmatic (oceanic) crustal thickness of c. $7.5 \mathrm{~km}$. The largest Moho depth, $21 \mathrm{~km}$, is measured beneath, and slightly landward of, the marginal high. A similar thickness is observed near the southwestern terminations of 3-99 and 4-99. Local Moho minima of $15 \mathrm{~km}$ are observed along the northeastern parts of these profiles. The average P-wave velocity below the Moho is measured to $8.2 \mathrm{~km} / \mathrm{s}$. No reliable S-wave arrivals penetrating these depths were measured.

\section{Discussion}

\subsection{COT and oceanic crust}

The COT, as indicated in Figs. 6a, 7a, 10a, covers the transitional area where Vp, density and Vp/Vs increase oceanward from continental to oceanic properties (Mjelde et al., 2005). The change, as observed on volcanic margins, is generally interpreted as gradual oceanward increase in the amount of 'oceanic' intrusions into thinned continental crust. The COT in the study area is found to be narrow, decreasing in width from c. $40 \mathrm{~km}$ along 1-99 to c. $10 \mathrm{~km}$ along 5-99. We define the Continent- 
Ocean-Boundary (COB) primarily based on the even sharper P-wave transition (c. 5.0-6.2 km/s) observed in the deepest sedimentary / oceanic 3A layer. This definition agrees with interpretations from the Vøring Margin (Mjelde et al., 2005). The unusually clear COB found along 1-00 (Fig. 1; Breivik et al., 2006) demonstrates that the COB along 2-99 is located c. $20 \mathrm{~km}$ landward of the 5.2-6.1 km/s transition for this profile. We relate the apparent misfit along 2-99 to increased uncertainties due to the loss of OBS 19.

Breivik et al. (2006) found that the COB at the Møre Margin was dipping downwards to the NW. The same can be inferred from the present data; along 1-99 the change from c. $6.5 \mathrm{~km} / \mathrm{s}$ to $6.7 \mathrm{~km} / \mathrm{s}$ in the main crustal layer occurs northwestward of the COB as defined in the layer above. The same is apparent for 299, and the elevated Moho at c. 45 km along 5-99 might be interpreted in similar terms. Mjelde et al. (2006; 2007b) interpreted the COB as a master fault, dipping downwards to the NW on the Møre Margin, and downwards to the SE on the Vøring Margin. The same general pattern of faulting has been found also in the basin area (Osmundsen et al. 2002). According to this model, the margin formation was dominated by detachment faulting, and the westernmost of these faults nucleated the COB. The new models from the Møre Margin are in agreement with the master fault hypothesis, but we underline that this interpretation is poorly constrained. If one assumes uniform stretching, a stretching factor of 1.7-2.0 is obtained for the 140-65 Ma period (Scheck-Wenderoth et al. 2007). However, these authors point out that the observed vertical movements suggest differential stretching with a dominant subcrustal extension.

The total (oceanic) magmatic crustal thickness formed at the seaward termination of the COT is $15 \mathrm{~km}$ along 1-99, decreasing to $7.5 \mathrm{~km}$ near the northwestward 
termination of the profile. The corresponding values for profiles 2-99 and 5-99 are 14$13 \mathrm{~km}$ and 11-7.5 km, respectively. This relatively rapid decay of breakup magmatism is in agreement with earlier observations (Breivik et al., 2006; Mjelde et al., 2005). Note that none of the profiles discussed here extend oceanwards to `normal`oceanic crust.

The COB defined from the OBS modeling is on the free-air gravity map (Fig. 16a) located near the transition from the marked gravity low in the Møre Basin to a gravity high at the Møre Marginal High. The magnetic data map (Fig. 16b) shows that the COB follows the trend of a magnetic low. The magnetic data on the marginal high are difficult to interpret, most likely due to the presence of the complex sequence of extrusives.

\subsection{LCB: distribution and age}

Fig. 17 shows the thickness of the (7.1-7.3 km/s) LCB in the study area, including the results farther landwards as discussed by Olafsson et al. (1992) and Mjelde et al. (2007b). The layer is thickest near the southwestern end of 4-99 (5 km), corresponding to an area with increased landward extent of the extrusives. The LCB is found to terminate in the northeastern part of the study area, and a local maximum follows profile 8-96 landwards. The LCB is inferred to terminate landwards of the Vigra High. As for the LCB in the Vøring Basin (e.g., Mjelde et al. 2008a), there appears to be no clear link between the distribution of the layer and basement topography; the layer is thick beneath the Vigra High but the layer thickness is also significant beneath the basement low along the southern part of 4-99. 
As summarized by Mjelde et al. (2008a), the physical properties of the LCB are in agreement with mafic (gabbroic) rocks, but the body may represent an old (Caledonian?) basement terrain (e.g., Ebbing et al., 2006), or lower crustal intrusions related to the last phase of rifting and breakup. Mjelde et al. (2008a) argue in favour of the younger emplacement hypothesis mainly for these reasons: 1 . The distribution of Early Tertiary sedimentary sills corresponds closely with the extent of the highvelocity layer, 2. Magmatic emplacement models, which account for observed extrusives and intrusives into the sedimentary section, require intrusions in the lower crust, 3. Crustal sections both to the east and west of the mid-Norwegian Margin are dominantly felsic. Some profiles across the Vøring Margin suggest continuity between the LCB and oceanic layer 3B across the COT (Mjelde et al., 2008a). The same is observed for all profiles on the Møre Margin, indicating a genetic link with the breakup magmatism.

Dividing the maximum thickness of the oceanic crust by the maximum thickness of the LCB estimated for the Vøring and Møre margins results in the same ratio; 2.7. This ratio is calculated by using average maximum oceanic crustal thickness of $23 \mathrm{~km}$ for Vøring (Mjelde et al., 2001) and $13.3 \mathrm{~km}$ for Møre, and maximum LCB thickness of $8.5 \mathrm{~km}$ and $5 \mathrm{~km}$ in the Vøring and Møre basins, respectively. This observation may suggest that the LCB is genetically related to the breakup magmatism.

The anomalous Early Tertiary magmatism has been related to the arrival of the Icelandic Plume, and processes related to the continental breakup itself (e.g., Mutter et al., 1988). Supporting arguments for the Iceland Hotspot representing a mantle plume (e.g., Saunders et al. 1997; Mjelde et al.; 2008c) come from: modelling of the North Atlantic geoid anomaly, dynamic plume modelling, link between Palaeogene transient uplift and a thermal anomaly, mantle tomography and geochemical studies. Breivik et 
al. (2006) argue that the observed correlation between spreading rate and magmatic productivity across the Møre Marginal High COT supports the plume hypothesis. Furthermore, the modelled seismic velocities are in agreement with the plume model (Kelemen and Holbrook, 1995; Breivik et al. 2006). The higher degree of magmatism on the Vøring Margin (active upwelling) may be related to this margin`s proximity to the Iceland Plume centre at the time of breakup (Breivik et al., 2006). Alternatively, it might indicate that the Vøring Margin represented a local centre of enhanced magma injection during continental breakup (Mjelde et al., 2001). The variations in LCB thickness in the basins are, according to the plume hypothesis, partly related to varying lithospheric thickness and hence decompression melting during extension. Pwave velocities as high as $7.6 \mathrm{~km} / \mathrm{s}$ were modeled locally within the LCB in the Vøring Basin (Mjelde et al. 2003a). These authors interpreted the strong lateral variations in $\mathrm{LCB}$ velocities $\left(\mathrm{V}_{\mathrm{p}}=7.1-7.6 \mathrm{~km} / \mathrm{s}\right)$ in terms of a heterogeneous mantle source or varying mantle potential temperature. Similar variations have not been observed along the Møre Margin.

Detailed knowledge on the break-up process has recently been obtained from a high-resolution OBS and multi-channel seismic profile off the Faroes (White et al. 2008). Their findings strongly suggest that the COT consists of a mixture of continental crust and intrusions (sills). In the Møre Margin profiles we observe an ocean-ward increase in P-wave velocity in the mid/lower crust from $6.6 \mathrm{~km} / \mathrm{s}$ landward of the COT to $6.9 \mathrm{~km} / \mathrm{s}$ within the COT, and $7.0 \mathrm{~km} / \mathrm{s}$ within the thickened oceanic crust. The average velocity in the lower crust is modeled to be $7.2 \mathrm{~km} / \mathrm{s}$. By interpreting the COT as a sill complex, our modeled velocities are consistent with passive, decompression melting of magma with c. $75^{\circ} \mathrm{C}$ increased temperature at break-up, but not with increased mantle fertility (White et al. 2008). 


\subsection{The Moho and $+8 \mathrm{~km} / \mathrm{s}$ bodies}

The Moho is by definition a velocity contrast below which the P-wave velocity is observed to increase to above c. $8.0 \mathrm{~km} / \mathrm{s}$. Generally, the Moho is interpreted to represent the top of the upper mantle (peridotite), and this interpretation may also be applied throughout our survey area. However, some important exceptions exist in this region. $>8 \mathrm{~km} / \mathrm{s}$ bodies have been interpreted as lower crustal eclogites related to the Caledonian Orogeny off western Norway (Christiansson et al., 2000). Eclogitized rocks are found onshore nearby in the Western Gneiss Region, western Norway (Andersen et al. 1991; Austrheim 1987). The eclogitization took place at a temperature of about $700^{\circ} \mathrm{C}$ and a pressure between 18 and 21 kbar (Jamtveit et al. 1990). A similar interpretation has been made for a lower crustal body observed in the southern Vøring Basin (Fig. 17; Raum et al., 2006) and close to the mainland off Møre (Olafsson et al., 1992; Mjelde et al., 2007b). We have indicated the thickness of the body in Møre Basin in Fig. 17. It is unlikely that the bodies represent upper mantle peridotites, since this hypothesis would imply almost complete and unrealistic extensional removal of the crystalline crust without observable influence on the sedimentary basin above (e.g., Raum et al., 2006). The LCB terminates at least $30 \mathrm{~km}$ northwestwards of the $>8 \mathrm{~km} / \mathrm{s}$ body, and the trend of the bodies is significantly different. These observations may indicate that they are genetically unrelated. We note that the $>8 \mathrm{~km} / \mathrm{s}$ body in the southern Vøring Basin was not included in the final model presented by Rouzo et al. (2006), who performed a 3D modeling of parts of the OBS data in that area. Their modeling was focused on the sedimentary and upper crystalline section, and did not include lower crustal/upper mantle arrivals. 
The gravity modeling of the three NW-SE striking profiles documents that the upper mantle density is c. $0.1 \mathrm{~g} / \mathrm{cm}^{3}$ smaller in the oceanic domain compared with the continental part (Figs. 6b,7b,10b). The same effect has been observed on the Vøring and SE Barents Sea margins, and is explained by the thermal effect from the oceanic spreading ridge (Breivik et al., 1999). A northward decrease in density is also observed along profiles 3-99 and 4-99, as they approach the COB. The effect is most prominent for the profile located closest to the COB (4-99), where the density decrease is modeled to $0.15 \mathrm{~g} / \mathrm{cm}^{3}$. The corresponding value for $3-99$ is $0.05 \mathrm{~g} / \mathrm{cm}^{3}$, which is close to the limit of resolution. The large difference observed along 4-99 suggests that part of the density anomaly may be attributed to a positive thermal anomaly related to the JMFZ.

\subsection{Crustal scale lineaments}

The OBS models clearly indicate the existence of the JML, from the landward termination of the JMFZ at the COB and c. $80 \mathrm{~km}$ landwards (Figs. 8a, 9a, 10a). Its possible continuation further landward is unknown due to lack of data. The slightly curved lineament is interpreted where the LCB terminates northeastwards. The lineament is marked as an abrupt eastward deepening of the Base Cretaceous interface along 2-99. The lineament is also clearly expressed in the top basement interface for 2-99 and 4-99, and it is related to a Moho high along 3-99 and 4-99. The lineament has no clear imprint in the gravity or magnetic maps (Fig. 16). In agreement with Doré et al. (1997) we interpret the JML as reactivated Proterozoic structuring. Alternatively, it may be considered as a hinge zone with dominantly normal-, and some strike-slip faulting, related to the JMFZ (Torske and Prestvik, 1991). 
The gravity map expresses a linear gravity high extending c. $150 \mathrm{~km}$ landwards from the COB, covering the southwestern part of 4-99. A part of this anomaly is also expressed as a magnetic high. At the location of OBS 7 (c. $40 \mathrm{~km}$ ) the profile is characterized by southwestward deepening of the crystalline basement and the Moho, and thickening of the LCB. It is not possible to determine whether these observations indicate the presence of another lineament, due to lack of OBS data further southwards in the basin.

The lineaments in the Vøring Basin, primarily interpreted from OBS data, seem to merge landwards into three different post-Caledonian detachments observed on the mainland and on the Trøndelag Platform (Osmundssen et al., 2002; Olesen et al., 2002; Ebbing et al., 2006; Mjelde et al., 2008a). Raum et al. (2006) infer a genetic relationship between the body interpreted as Caledonian eclogites in the southern Vøring Basin and the later development of the Vøring Transform Margin (Jan Mayen Fracture Zone). Following the observations from the Vøring Margin, we speculate that the Jan Mayen Lineament as defined by our study, may continue landwards and link up with the fourth post-Caledonian detachment observed on the mainland, the NS-trending Nordfjord-Sogn Detachment (NSD) - Klakk Fault System (Johnston et al., 2007; Fig. 17). The NSD represents the post-Caledonian detachment west of which lower crustal eclogites were inferred by Christiansson et al. (2002), and Fig. 17 shows that the NSD may relate to the eastern Møre Basin eclogites in a similar fashion. This interpretation would be in agreement with the gravity data, expressing a positive anomaly here (Fig. 16a). In order to test this idea, additional OBS data are needed landward of the present survey (i.e. at c. $62^{0}-65^{0} \mathrm{~N}$ and $4^{0}-8^{0} \mathrm{E}$ ).

Note that the detachment, if it exists here, has been overprinted by significant right-lateral shear along the MTFZ during the Permian-Cretaceous extensional 
episodes (Gabrielsen et al., 1999). Furthermore, the offshore part of the MTFZ was associated with subsidence and basin formation in Paleocene (Scheck-Wenderoth et al., 2007). This extension was related to olivine-nephelite volcanism, formed by partial melting of small mantle magma chambers (Bugge et al., 1980). Torske and Prestvik (1991) postulated that the emplacement of these alkaline rocks was related to the presence of a major transfer fault (the JML).

\section{Summary and conclusions}

- $\quad$ Five OBS profiles acquired along the northwestern part of the Møre Margin have been modeled with regard to P-waves and Vp/Vs-ratios. The models have been constrained by available MCS data, 2D gravity modeling, and gravity and magnetic data.

- $\quad$ The COT covers the transitional area where $\mathrm{Vp}$, density and $\mathrm{Vp} / \mathrm{Vs}$ increase oceanwards from continental to oceanic properties. The COT in the study area is found to be narrow, decreasing in width from c. $40 \mathrm{~km}$ along 1-99 to c. 10 $\mathrm{km}$ along 5-99. We define the COB primarily based on the sharp P-wave transition (c. 5.0-6.2 km/s) observed in the deepest sedimentary / oceanic 3A layer.

- The total (oceanic) magmatic crustal thickness formed at the seaward termination of the COT is modeled to $11-15 \mathrm{~km}$, decreasing to c. $7.5 \mathrm{~km}$ near the northwestward termination of the profiles. This relatively rapid decay of breakup magmatism is in agreement with earlier observations (Breivik et al., 2006). 
- The maximum thickness of the post-breakup sedimentary sequence modeled in the Møre Basin is $3 \mathrm{~km}$. The corresponding values for the Cretaceous and pre-Cretaceous are $8 \mathrm{~km}$ and $6.5 \mathrm{~km}$, respectively.

- $\quad$ The upper continental crystalline basement is underlain by a high-velocity layer (7.1-7-3 km/s; LCB), which continues with indistinguishable physical properties into oceanic layer 3B across the COT. The ratio between the maximum thickness of the mafic oceanic crust and the maximum thickness of the LCB for the Vøring and Møre margins is the same; 2.7. These observations suggest that the LCB is genetically related to the breakup magmatism.

- The depth to the Moho, which is interpreted as the top of the mantle throughout the survey area, is estimated at $11 \mathrm{~km}$ along the northwestern part of profile 1-99. The largest Moho depth, $21 \mathrm{~km}$, is measured beneath the landward part of the marginal high. Local Moho minima of $15 \mathrm{~km}$ are observed along the northeastern part of profiles 3-99 and 4-99.

- The OBS models clearly indicate the existence of the JML, from the landward termination of the JMFZ at the COB and c. $80 \mathrm{~km}$ landwards. The slightly curved lineament is interpreted where the LCB terminates northeastwards. The lineament is also observed as structuring in the Base Cretaceous interface, top basement and the Moho for several profiles. The lineament has no clear imprint in the gravity or magnetic maps.

- We speculate that the JML may continue landwards and link up with the NStrending Nordfjord-Sogn Detachment - Klakk Fault System.

\section{Acknowledgments}


The crew of R/V Håkon Mosby and engineers from the University of Bergen are greatly acknowledged for their skills and help in all possible situations. The same applies to H. Shimamura, S. Akiyama, A. Kuwano and T. Yamashina from Hokkaido University. We also thank geoscientists from the NPD and Norsk Hydro for their strong efforts and assistance during the planning of the survey, which was mostly funded by Norsk Hydro. In particular we thank Ridvan M. Karpuz and Richard Whittaker from Norsk Hydro and Unni W. Næss and Harald Brekke from the NPD. We finally thank Ole Jacob Sandal for processing the navigation data, Colin Zelt for providing permission to use the inversion/forward modeling software, and Harm Van Avendonk, Donna Shillington, Laurent Gernigon and one anonymous reviewer for very constructive comments.

\section{References}

Andersen, O.B., Knudsen, P., 1998. Global marine gravity field from the ERS-1 and Geosat geodetic mission altimetry. J. Geophys. Res. 103, C4, 8129.

Andersen, T.B., Jamtveit, B., Dewey, J.F., Swensson, E., 1991. Subduction and eduction of continental crust: major mechanism during continent-continent collision and orogenic extensional collapse, a model based on the south Norwegian Caledonides. Terra Nova 3, 303-310.

Austrheim, H., 1987. Eclogitization of lower crustal granulites by fluid migration through shear zones. Earth and Planet Science Letters 81, 221-232. 
Blystad, P., Brekke, H., Færseth, R.B., Skogseid, J., Tørudbakken, B., 1995.

Structural elements of the Norwegian continental shelf. Part 2: The Norwegian Sea Region. NPD Bull. No 8 (Norwegian Petroleum Directorate).

Brekke, H., Sjulstad, H.I., Magnus, C., Williams, R.W., 2001. Sedimentary environments offshore Norway - an overview. In: Martinse, O.J., Dreyer, T. (Eds), Sedimentary environments offshore Norway - Palaeozoic to Recent. NPF Special Publication 10, Elsevier, Amsterdam, 7-37.

Breivik, A.J. Verhoef, J., Faleide, J.I., 1999. Effect of thermal contrasts on gravity modelling at passive margins: Results from the western Barents Sea. Journal of Geophysical Research 104, 15293-15311.

Breivik, A.J., Mjelde, R., Faleide, J.I., Murai, Y., 2006. Rates of continental breakup magmatism and seafloor spreading in the Norway Basin - constraints on Iceland Plume activity. J. Geophys. Res. 111, B07103, 1-17.

Bugge, T., Prestvik, T., Rokoengen, K., 1980. Lower Tertiary volcanic rocks off Kristiansund - Mid Norway. Mar. Geol. 35, 277-286.

Christiansson, P., Faleide, J.I., Berge, A.M., 2000. Crustal structure in the northern North Sea: an integrated geophysical study. In: Nøttvedt, A. (Ed), Dynamics of the Norwegian Margin. Geological Society of London Special Publication 167, 55-40. 
Chung, T.W., Hirata, N., Sato, R., 1990. Two-dimensional P- and S-wave velocity structure of the Yamato Basin, the southern Japan Sea, from refraction data collected by an Ocean Bottom Seismograph array. J. Phys. Earth. 38, 99-147.

Domenico, S.N., 1984. Rock lithology and porosity determination from shear and compressional wave velocity. Geophysics 49, 1188-1195.

Doré, A.G., Lundin, E.R., Fichler, C., Olesen, O., 1997. Patterns of basement structure and reactivation along the NE Atlantic margin. Journal of the Geological Society, London 154, 85-92.

Ebbing, J., Lundin, E., Olesen, O., Hansen, E.K., 2006. The mid-Norwegian margin: A discussion of crustal lineaments, mafic intrusions, and remnants of the Caledonian root by 3D density modelling and structural interpretation. Journal of the Geological Society, London 163, 47-59.

Eldholm, O., Thiede, J., Taylor, E., 1989. Evolution of the Vøring Volcanic Margin, Proc. ODP, Sci. Results, 104, College Station, TX (Ocean Drilling Program), 10331065.

Gabrielsen, R., Odinsen, T., Grunnaleite, I., 1999. Structuring of the Northern Viking Graben and the Møre Basin; the influence of basement structural grain and the particular role of the Møre-Trøndelag Fault Complex. Marine and Petroleum Geology $16,443-465$. 
Gernigon, L., Ringenbach, J.S., Planke, S., Le Gall, B., 2004. Deep structures and breakup along volcanic rifted margins: insights from integrated studies along the outer Vøring Basin (Norway). Marine and Petroleum Geology 21, 363-372.

Haflidason, H., Sejrup, H. P., Nygård, A., Mienert, J., Bryn, P., Lien, R., Forsberg, C. F., Berg, K., Masson, D., 2004. The Storegga Slide: architecture, geometry and slidedevelopment. Marine Geology 213, 201-234.

Holbrook, W.S., Mooney, W.D., Christensen, N.J., 1992. The seismic velocity structure of the deep continental crust. In: Fountain, D.M., Arculus, R., Kay, R.W. (Eds), Continental Lower Crust. Development in Geotectonics 23, Elsevier, Amsterdam, 1-43.

Jamtveit, B., Bucher-Nurminen, K., Austrheim, H., 1990. Fluid controlled eclogitization of granulites in deep crustal shear zones, Bergen arcs, Western Norway. Contributions in Mineralogy and Petrology 104, 184-193.

Johnston, S.M., Hacker, B.R., Andersen, T.B., 2007. Exuming Norwegian ultrahighpressure rocks: Overprinting extensional structures and the role of the Nordfjord-Sogn Detachment Zone. Tectonics 26, doi:10.1029/2005TC001933.

Kelemen, P.B., Holbrook, W.S., 1995. Origin of high-velocity, igneous crust along the U.S. East Coast Margin. Journal of Geophysical Research 100, 10077-10094.

Kimbell, G.S., Ritchie, J.D., Johnson, H., Gatlif, R.W., 2005. Controls on the structure and evolution of the NE Atlantic margin revealed by regional 3D gravity modelling. In: Doré, A.G., Vining, B.A. (Eds), Petroleum Geology: North-West 
Europe and Global Perspectives-Proceedings of the 6th Petroleum Geology

Conference. Geological Society of London, 933-947.

Ludwig, J.W., Nafe, J.E., Drake, C.L., 1970. Seismic refraction. In: Maxell, A.E. (Ed), The Sea 4. Wiley, New York, 53-84.

Mjelde, R., Kodaira, S., Shimamura, H., Kanazawa, T., Shiobara, H., Berg, E.W., Riise, O., 1997. Crustal structure of the central part of the Vøring basin, mid-Norway margin, from ocean bottom seismographs. Tectonophysics 277, 235-257.

Mjelde, R., Raum, T., Myhren, B., Shimamura, H., Murai, Y., Takanami, T., Karpuz, R., Næss, U., 2001. Continent-ocean transition on the Vøring Plateau, NE Atlantic, derived from densely sampled ocean bottom seismometer data. Journal of Geophysical Research 110, B05101, 1-19.

Mjelde, R., Fjellanger, J.P., Raum, T., Digranes, P., Kodaira, S., Breivik, A. and Shimamura, H., 2002. Where do P-S converions occur? Analysis of OBS-data from the NE Atlantic Margin. First Break 20.3, 153-160.

Mjelde, R., Shimamura, H., Kanazawa, T., Kodaira, S., Raum, T., Shiobara, H., $2003 a$. Crustal lineaments, distribution of lower crustal intrusives and structural evolution of the Vøring Margin, NE Atlantic; new insight from wide-angle seismic models. Tectonophysics 369, 199-218.

Mjelde, R., Raum, T., Digranes, P., Shimamura, H., Kodaira, S., $2003 b$. 
Vp/Vs-ratio along the Vøring Margin, NE Atlantic, derived from OBS-data;

Implications on lithology and stress-field. Tectonophysics 369, 175-197.

Mjelde, R., Raum, T., Myhren, B., Shimamura, H., Murai, Y., Takanami, T., Karpuz, R., Næss, U., 2005. Continent-Ocean-Transition on the Vøring Plateau, NE Atlantic, derived from densely sampled ocean bottom seismometer data. Journal of Geophysical Research 110, B05101, 1-19.

Mjelde, R., Raum, T., Murai, Y., Takanami, T., 2006. Continent-ocean-transitions: Review, and a tectono-magmatic model of the Vøring Plateau. Journal of Geodynamics doi:10.1016/j.jog.2006.09.013.

Mjelde, R., Faleide, J.I., Breivik, A.J., Raum, T., Wilson, J. 2008a. Lower crustal composition and crustal lineaments on the Vøring Margin, NE Atlantic: A review. Tectonophysics, (In press).

Mjelde, R., Raum, T., Breivik, A.J., Faleide, J.I. 2008b. Crustal transect across the North Atlantic. Marine Geophysical Researches (In press).

Mjelde, R., Breivik, A.J., Raum, T., Mittelstaedt, E., Ito, G., Faleide, J.I. 2008c. Magmatic and tectonic evolution of the North Atlantic. Journal of the Geological Society 165, 31-42. 
Mutter, J.C., Buck, W.R., Zehnder, C.M., 1988. Convective partial melting, a model for the formation of thick basaltic sequences during the initiation of spreading. Journal of Geophysical Research 93, 1031-1048.

Olafsson, I., Sundvor, E., Eldholm, O., Grue, K., 1992. Møre Margin: crustal structures from analysis of expanded spread profiles. Mar. Geophys. Res. 14, 137-162.

Olesen, O., Lundin, E., Nordgulen, Ø., Osmundsen, P.T., Skilbrei, J.R. Smethurst, M.A., Solli, A., Bugge, T., Fichler, C., 2002. Bridging the gap between the onshore and offshore geology in Nordland, northern Norway. Norwegian Journal of Geology 82, 243-262.

Olesen, O., Ebbing, J., Lundin, E., Mauring, E., Skilbrei, J.R., Torsvik, T.H., Hansen, E.K., Henningsen, T., Midbøe, P., Sand, M., 2007. An improved tectonic model for the Eocene opening of the Norwegian-Greenland Sea: use of modern magnetic data. Marine and Petroleum Geology, submitted.

Osmundsen, P.T., Sommeruga, A., Skilbrei, J.R., Olesen, O., 2002. Deep structure of the Mid Norway rifted margin. Norwegian Journal of Geology 82, 205-224.

Raum, T., 2000. Crustal structure and evolution of the Faroe, Møre and Vøring margins from wide-angle seismic and gravity data. Ph.D. thesis, University of Bergen, 114 pp. 
Raum, T., Mjelde, R., Digranes, P., Shimamura, H., Shiobara, H., Kodaira, S., Haatvedt, G., Sørenes, N., Thorbjørnsen, T., 2002. Crustal structure of the southern part of the Vøring Basin, mid-Norway margin, from wide-angle seismic and gravity data. Tectonophysics 355, 99-126.

Raum, T., Mjelde, R., Shimamura, H., Murai, Y., Bråstein, E., Karpuz, R.M., Kravik, K., Kolstø, H.J., 2006. Crustal structure and evolution of the southern Vøring Basin and Vøring Transform Margin, NE Atlantic. Tectonophysics 415, 167-202.

Riis, F., Fjeldskaar, W., 1992. On the magnitude of the late Tertiary and Quaternary erosion and its significance for the uplift of Scandinavia and the Barents Sea. In: Larsen, R.M., Brekke, H., Larsen, B.T., Talleraas, E. (Eds), Structural and Tectonic Modeling and its Application to Petroleum Geology. NPF Special Publication 1, Elsevier, Amsterdam, 163-185.

Rouzo, S., Klingelhoefer, F., Jonquet-Kolstø, H., Karpuz, R., Kravik, K., Mjelde, R., Murai, Y., Raum, T., Shimamura, H., Williamson, P., Geli, L., 2006. 2D and 3D modelling of wide-angle seismic data: an example from the Vøring volcanic passive margin. Marine Geophysical Researches 27, 181-199.

Scheck-Wenderoth, M., Raum, T., Faleide, J.I., Mjelde, R., Horsfield, R., 2007. The transition from the continent to the ocean - a deeper view on the Norwegian Margin. J. Geol. Soc. 164, 855-868. 
Torske, T., Prestvik, T., 1991. Mesozoic detachment in the Norwegian-Greenland Sea Region: Evidence from Jan Mayen Fracture Zone and associated alkaline volcanics? Geology 19, 481-485.

Verhoef, J., Roest, W.R., Macnab, R., Arkani-Hamed, J., 1996. Magnetic anomalies of the Arctic and north Atlantic oceans and adjacent areas. Tech. Rep., Geol. Surv. Canada, Dartmouth.

White, R.S., McKenzie, D., O'Nions, J. 1992. Oceanic crustal thickness from seismic measurements and rare earth element inversion. J. Geophys. Res. 97, 19683-19715.

White, R.S., Smith, L.K, Roberts, A.W., Christie, P.A.F., Kuznir, N.J., iSimm Team. 2008. Lower-crustal intrusion on the North Atlantic continental margin. Nature 452, 460-464.

Zelt, C.A., Smith, R.B., 1992. Seismic traveltime inversion for 2-D crustal velocity structure. Geophys. Journ. Int. 108, 16-34.

Zelt, C,A., Forsyth, D.A., 1994. Modeling wide-angle seismic data for crustal structure: Southeastern Grenville Province. J. Geophys. Res. 99, 11687-11704.

\section{Figure captions}

Fig. 1. Study area with main geological structures from Blystad et al. (1995). OBS profiles acquired in the period 1988-2000 are indicated. The 1999 profiles modeled 
for this paper are shown as black lines, on which dots represent positions of OBSs (see Figs. 6a-10a for OBS number). The ESP profile discussed by Olafsson et al. (1992) is indicated as `ESP`.

Fig. 2. a) Vertical component data recorded on OBS 10, profile 1-99, 5-15 Hz bandpass filtered, plotted with $4 \mathrm{~s}$ AGC and 8 km/s reduction velocity. b) Fit between observed (interpreted; hatched lines) and calculated (solid lines) travel-time curves. c) Calculated ray paths through the model shown in Fig. 6a. Cb: crystalline basement, $\mathrm{P}_{\mathrm{n}}$ : Moho refraction, $\mathrm{P}_{\mathrm{M}} \mathrm{P}$ : reflection at Moho, $\mathrm{U}_{\mathrm{M}}$ : upper mantle reflector.

Fig. 3. a) Vertical component data recorded on OBS 7, profile 1-99, 5-15 Hz bandpass filtered, plotted with $4 \mathrm{~s}$ AGC and $8 \mathrm{~km} / \mathrm{s}$ reduction velocity. b) Fit between observed (interpreted; hatched lines) and calculated (solid lines) travel-time curves. c) Calculated ray paths through the model shown in Fig. $6 a$. $B_{a s}$ : basalt, $B_{c r}$ : Base Cretaceous, fl: floating reflector, Cb: crystalline basement, $\mathrm{P}_{\mathrm{n}}$ : Moho refraction, $\mathrm{P}_{\mathrm{M}} \mathrm{P}$ : reflection at Moho, $\mathrm{U}_{\mathrm{M}}$ : upper mantle reflector.

Fig. 4. a) Vertical component data recorded on OBS 38, profile 5-99, 5-15 Hz bandpass filtered, plotted with $4 \mathrm{~s}$ AGC and 8 km/s reduction velocity. b) Fit between observed (interpreted; hatched lines) and calculated (solid lines) travel-time curves. c) Calculated ray paths through the model shown in Fig. 10a. $\mathrm{U}_{\mathrm{M}}$ : upper mantle reflector.

Fig. 5. a) Vertical component data recorded on OBS 21, profile 5-99, 5-15 Hz bandpass filtered, plotted with $4 \mathrm{~s}$ AGC and $8 \mathrm{~km} / \mathrm{s}$ reduction velocity. b) Fit between observed (interpreted; hatched lines) and calculated (solid lines) travel-time curves. c) 
Calculated ray paths through the model shown in Fig. 10a. $\mathrm{B}_{\mathrm{as}}$ : basalt, $\mathrm{T}_{\mathrm{u}}$ : Turonian, $\mathrm{C}_{\mathrm{e}}$ : Cenomanian, $\mathrm{B}_{\mathrm{cr}}$ : Base Cretaceous, Cb: crystalline basement, $\mathrm{P}_{\mathrm{M}} \mathrm{P}$ : reflection at Moho, $\mathrm{U}_{\mathrm{M}}$ : upper mantle reflector.

Fig. 6. a) P-wave model for profile 1-99. Numbers are P-wave velocities in $\mathrm{km} / \mathrm{s}$ and circled numbers are Vp/Vs-ratios. The white area represents the COT within which the COB has been interpreted (see text). OBS numbers are indicated on the seafloor. Ple: Pleistocene, Pli: Pliocene, BT: Base Tertiary, Tu: Turonian, Ce: Cenomanian, Al: Albian, BC: Base Cretaceous. b) Observed and calculated free-air gravity anomalies, and the gravity model for profile 1-99. Densities in $\mathrm{g} / \mathrm{cm}^{3}$.

Fig. 7. a) P-wave model for profile 2-99. Numbers are P-wave velocities in $\mathrm{km} / \mathrm{s}$ and circled numbers are Vp/Vs-ratios. See Fig. 6 caption for details. b) Observed and calculated free-air gravity anomalies, and the gravity model for profile 2-99. Densities in $\mathrm{g} / \mathrm{cm}^{3}$.

Fig. 8. a) P-wave model for profile 3-99. Numbers are P-wave velocities in km/s and circled numbers are Vp/Vs-ratios. See Fig. 6 caption for details. b) Observed and calculated free-air gravity anomalies, and the gravity model for profile 3-99. Densities in $\mathrm{g} / \mathrm{cm}^{3}$.

Fig. 9. a) P-wave model for profile 4-99. Numbers are P-wave velocities in km/s and circled numbers are Vp/Vs-ratios. See Fig. 6 caption for details. b) Observed and calculated free-air gravity anomalies, and the gravity model for profile 4-99. Densities in $\mathrm{g} / \mathrm{cm}^{3}$. 
Fig. 10. a) P-wave model for profile 5-99. Numbers are P-wave velocities in km/s and circled numbers are Vp/Vs-ratios. See Fig. 6 caption for details. b) Observed and calculated free-air gravity anomalies, and the gravity model for profile 5-99. Densities in $\mathrm{g} / \mathrm{cm}^{3}$.

Fig. 11. a) Horizontal component data recorded on OBS 10, profile 1-99, 5-15 Hz band-pass filtered, plotted with $4 \mathrm{~s}$ AGC and 8 km/s reduction velocity. b) Fit between observed (interpreted; hatched lines) and calculated (solid lines) PSS travel-time curves. c) Fit between observed (interpreted; hatched lines) and calculated (solid lines) PPS travel-time curves. d) Calculated PSS ray paths through the model shown in Fig. 6a. e) Calculated PPS ray paths through the model shown in Fig. 6a. Cb: crystalline basement, $\mathrm{P}_{\mathrm{M}} \mathrm{S}$ : P-to-S conversion at Moho.

Fig. 12. a) Horizontal component data recorded on OBS 38, profile 5-99, 5-15 Hz band-pass filtered, plotted with $4 \mathrm{~s}$ AGC and $8 \mathrm{~km} / \mathrm{s}$ reduction velocity. b) Fit between observed (interpreted; hatched lines) and calculated (solid lines) PSS travel-time curves. c) Fit between observed (interpreted; hatched lines) and calculated (solid lines) PPS travel-time curves. d) Calculated PSS ray paths through the model shown in Fig. 10a. e) Calculated PPS ray paths through the model shown in Fig. 10a. $S_{M} S$ : Sreflection at Moho, $\mathrm{P}_{\mathrm{M}} \mathrm{S}$ : P-to-S conversion at Moho.

Fig. 13. Average chi-squared values versus depth for all profiles. 
Fig. 14. Ray paths for calculated arrivals along profile 1-99 (some critical refracted head-waves not included). a) pre-Cretaceous/oceanic 3A, b) crystalline basement/oceanic 3A, c) LCB/oceanic 3B, d) Moho.

Fig. 15. Ray paths for calculated arrivals along profile 2-99 (some critical refracted head-waves not included). a) pre-Cretaceous/oceanic 3A, b) crystalline basement/oceanic 3A, c) LCB/oceanic 3B, d) Moho.

Fig. 16 a) ERS-1 (KMS-version) based free-air gravity map of the study area (Andersen and Knudsen, 1998). b) Magnetic map of the study area (Verhoef et al., 1996). COB: Continent-Ocean-Boundary.

Fig. 17. Thickness of the lower crustal high-velocity layer, contour interval in km. Red: > $8 \mathrm{~km} / \mathrm{s}$ body interpreted as eclogitized rocks. Orange: $>7 \mathrm{~km} / \mathrm{s}$ body (LCB) thicker than $5 \mathrm{~km}$. Yellow: LCB thinner than $5 \mathrm{~km}$ thick. The part of the map covering the Vøring Margin is from Mjelde et al. (2008a), while the Møre Margin part includes this study and the results from the two profiles presented by Olafsson et al. (1992) and Mjelde et al. (2008b). SBL: Scoresby-Bergen Lineament, postulated by Brekke et al. (2001). NSD: Nordfjord-Sogn Detachment.

\section{Table captions}

Tab. 1. RMS misfit values for the five profiles, grouped into six layers. 
Sheet1_2

\begin{tabular}{|c|c|c|c|c|c|c|}
\hline & \multicolumn{5}{|c|}{ RMS misfit } \\
\hline layer & line 1 & line 2 & line 3 & line 4 & line 5 \\
\hline 1 & 0.1260 & 0.1295 & 0.1195 & 0.1620 & 0.0890 \\
\hline 2 & 0.0725 & 0.0400 & 0.0845 & 0.0650 & 0.0765 \\
\hline 3 & 0.0655 & 0.0750 & 0.0450 & 0.0890 & 0.0615 \\
\hline 4 & 0.0735 & na & 0.0655 & 0.0555 & 0.0705 \\
\hline 5 & 0.0795 & 0.0825 & 0.0550 & 0.0740 & 0.0770 \\
\hline 6 & 0.0640 & 0.0700 & 0.0630 & 0.0845 & 0.0580 \\
\hline
\end{tabular}

1. Post-opening layers

Legend

2. Basalt and inner-flows

3. Cretaceous and pre-opening Tertiary layers

4. Pre-Cretaceous layer(s)

5. Crystalline basement and lower crust

6. Upper Mantle 


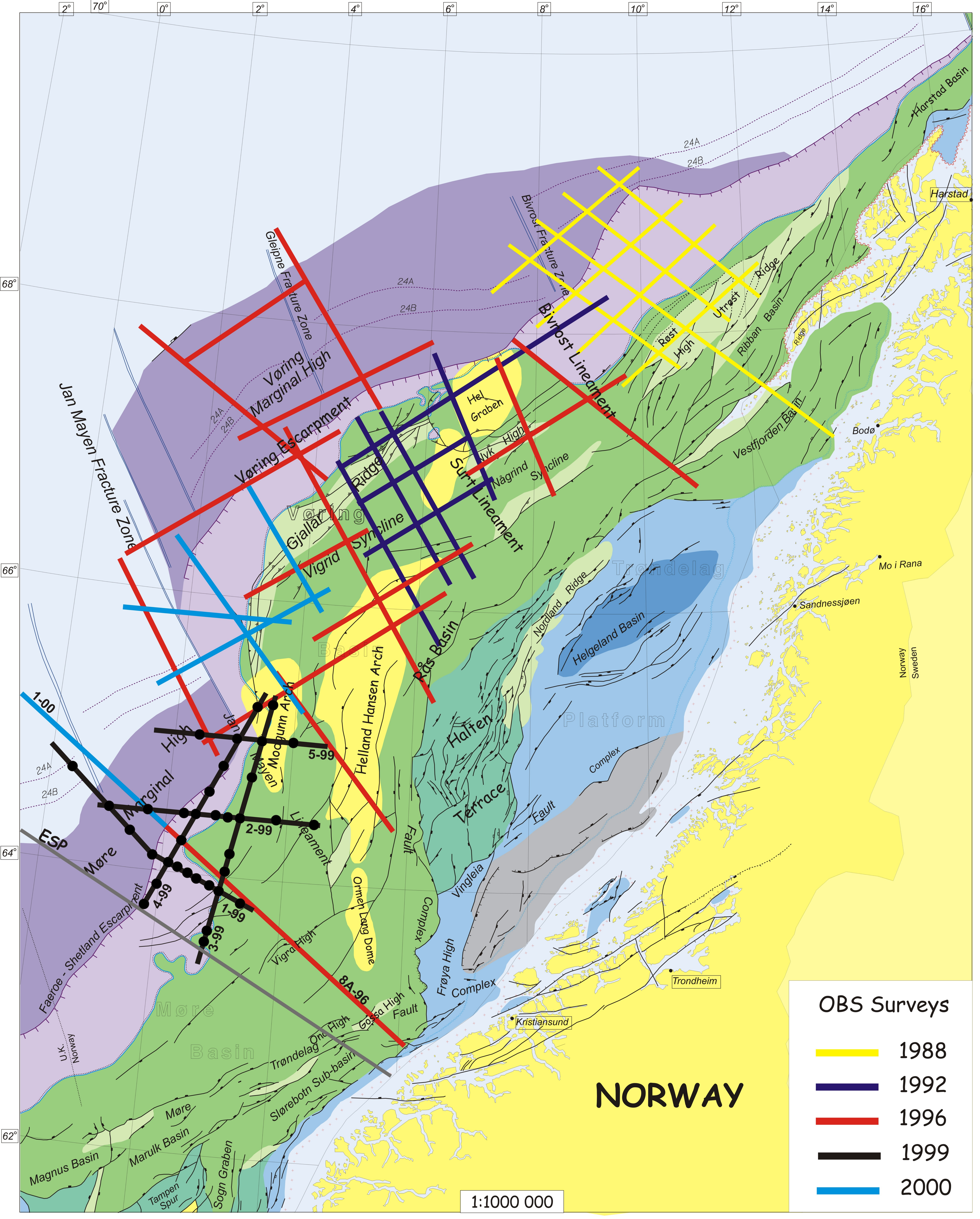




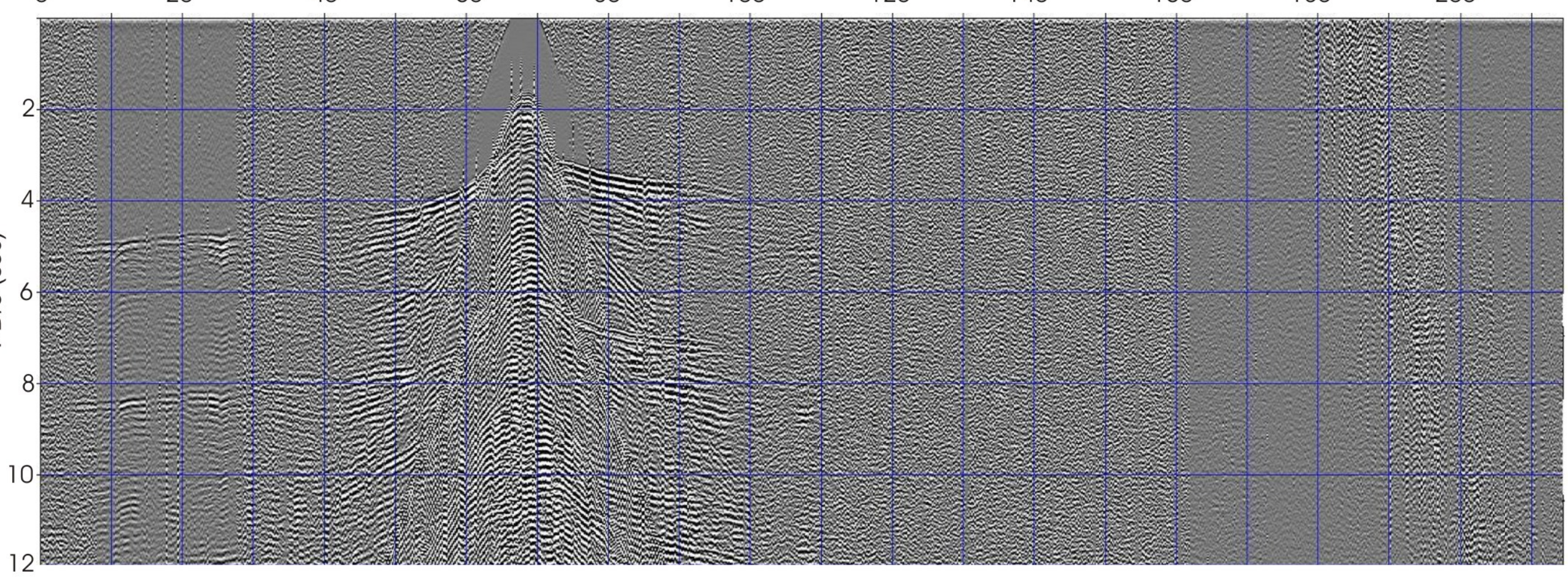

MjeldeMøre. fig 2a 


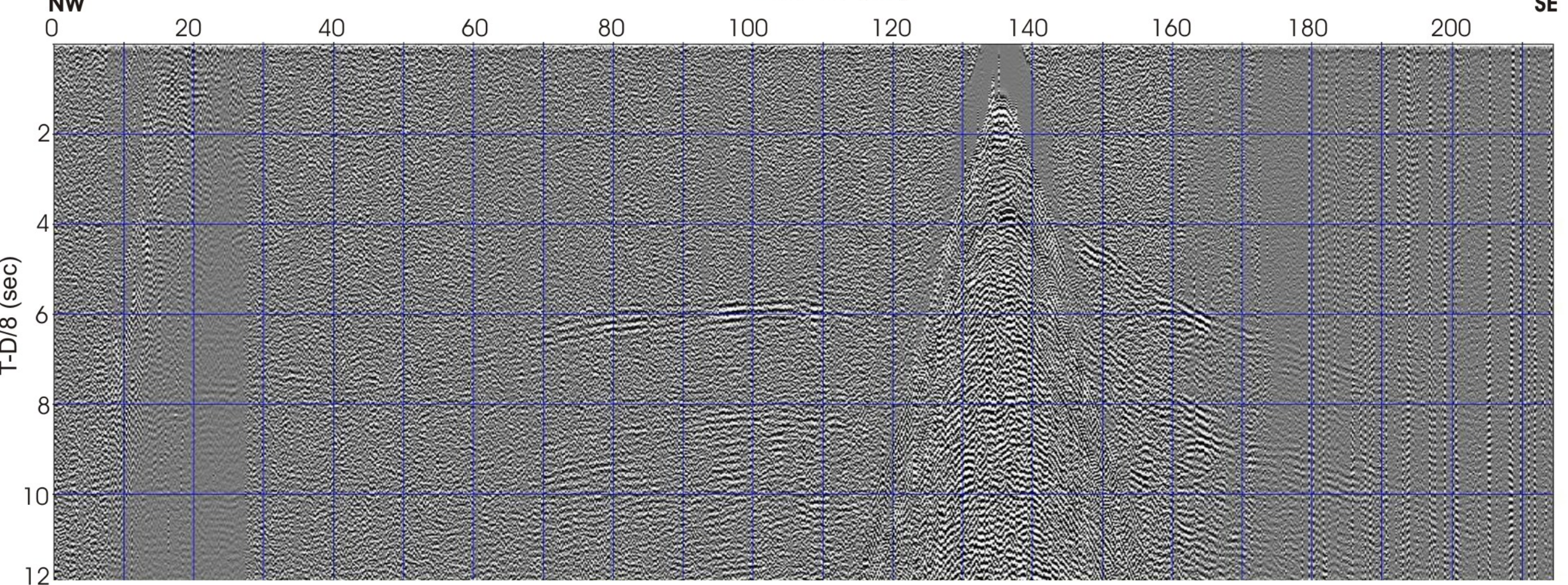




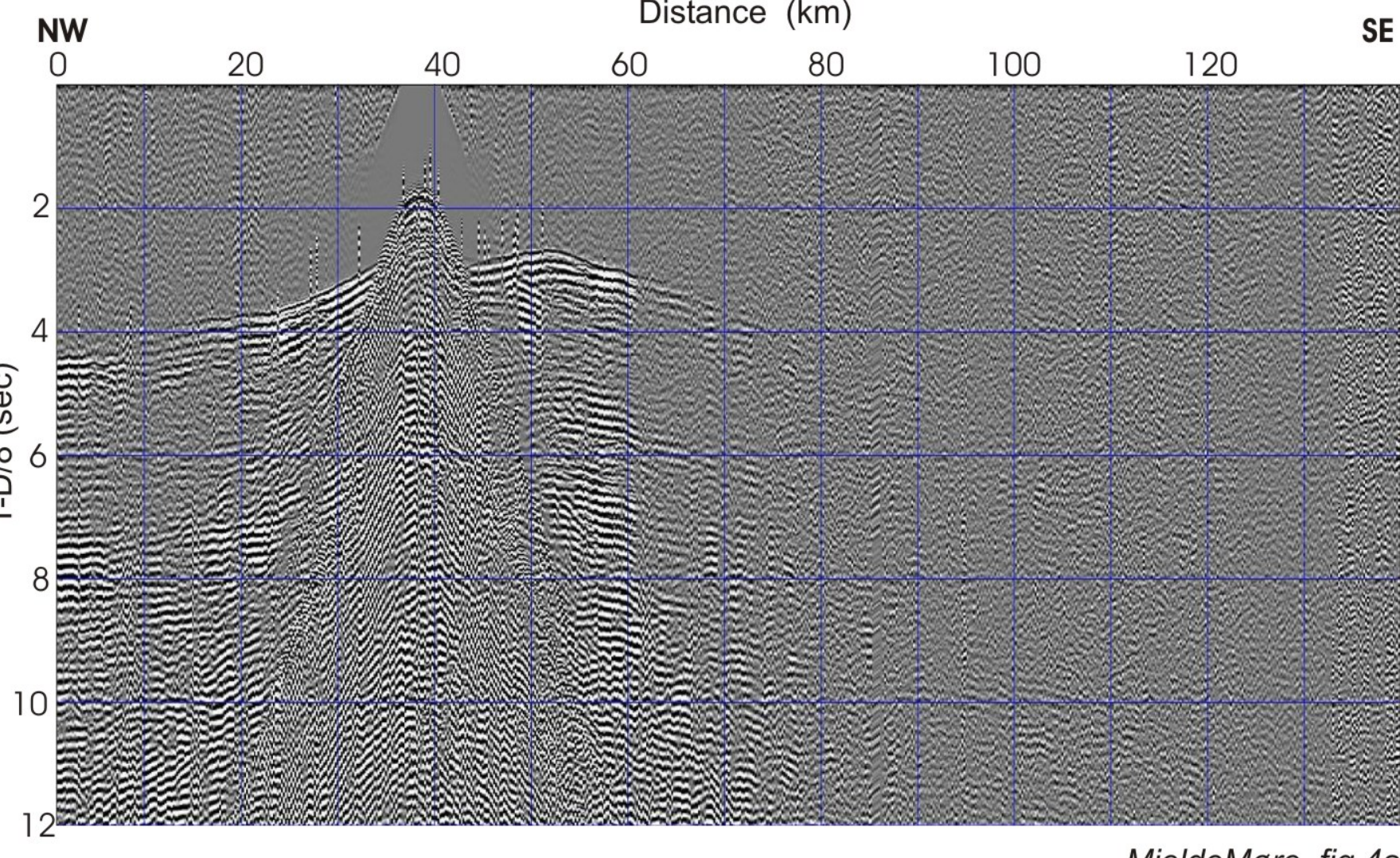

MjeldeMøre. fig 4a 


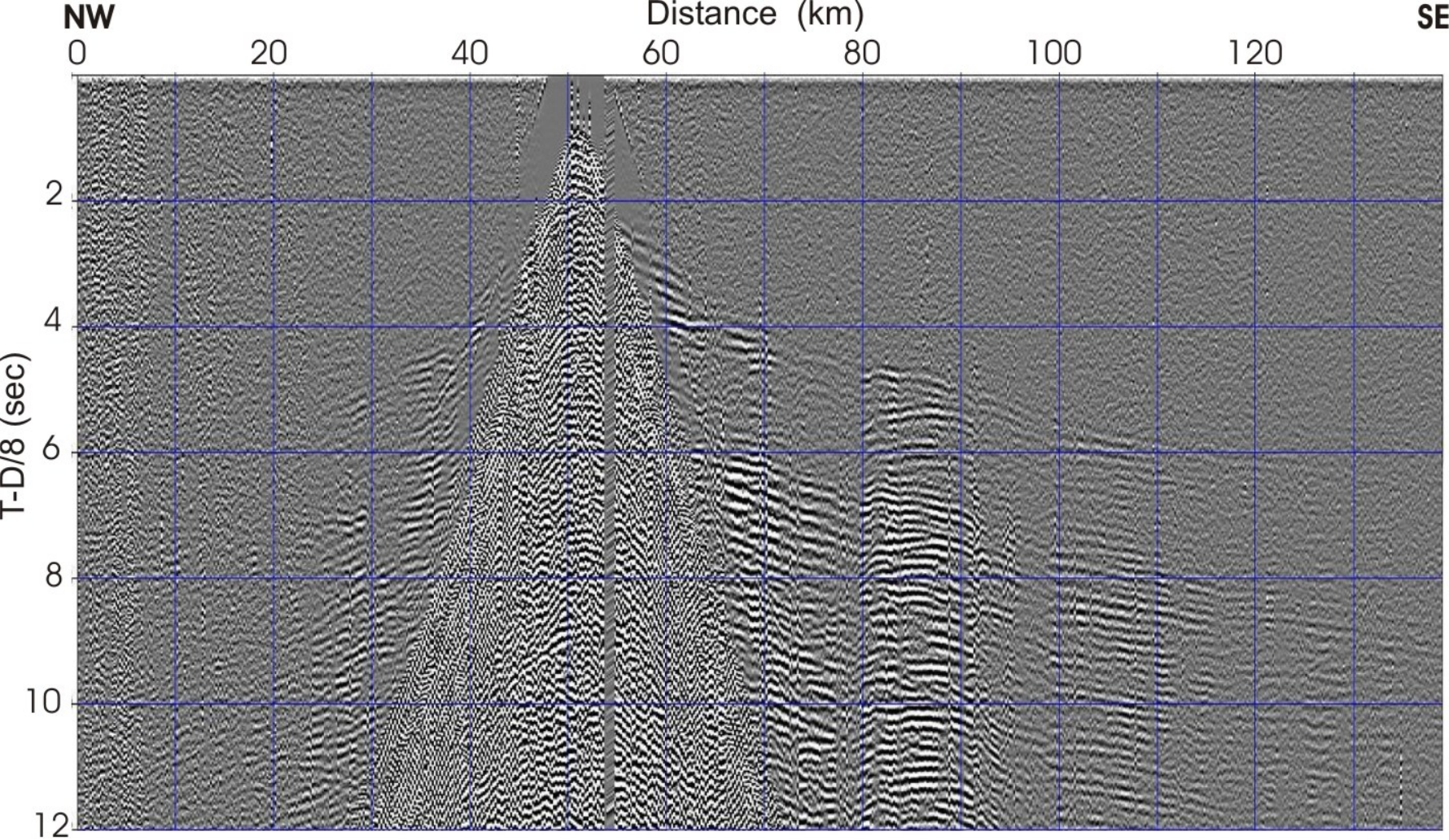

MjeldeMøre. fig 5a 


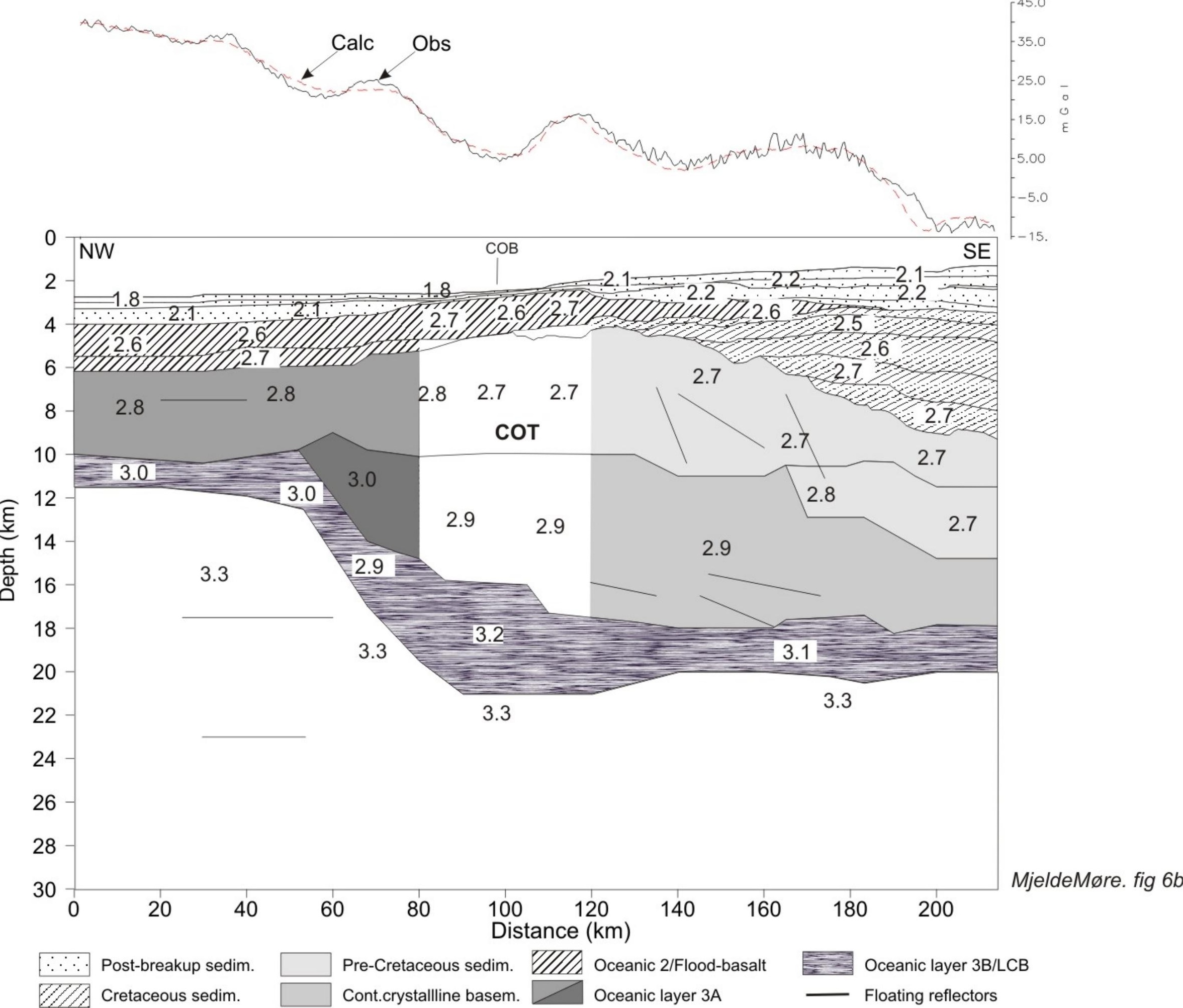




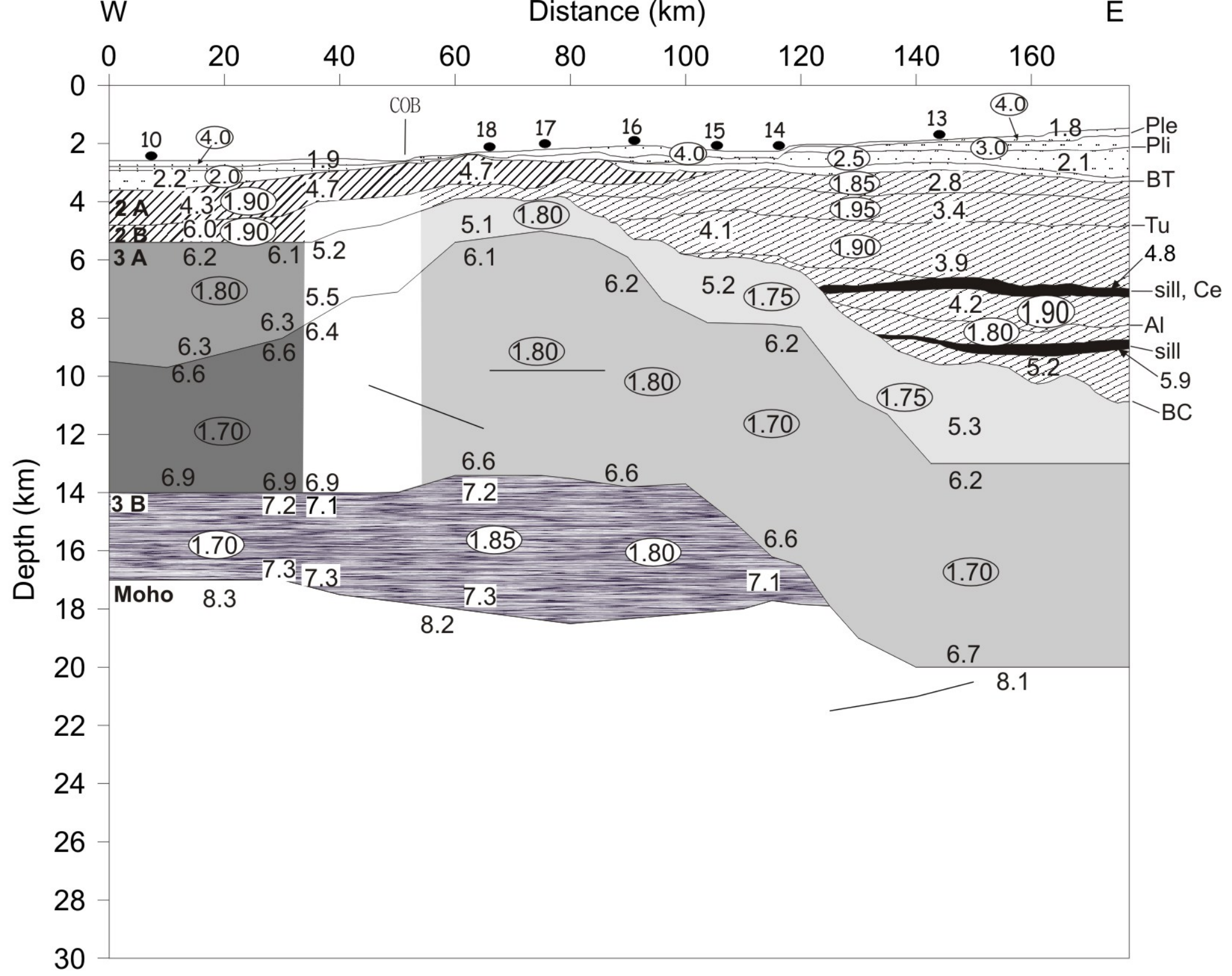

Post-breakup sedim. Cretaceous sedim.
Pre-Cretaceous sedim. Cont.crystalline basem.
Oceanic 2/Flood-basalt Oceanic layer $3 \mathrm{~A}$
Oceanic layer 3B/LCB

Floating reflectors

MjeldeMøre. fig 7a 


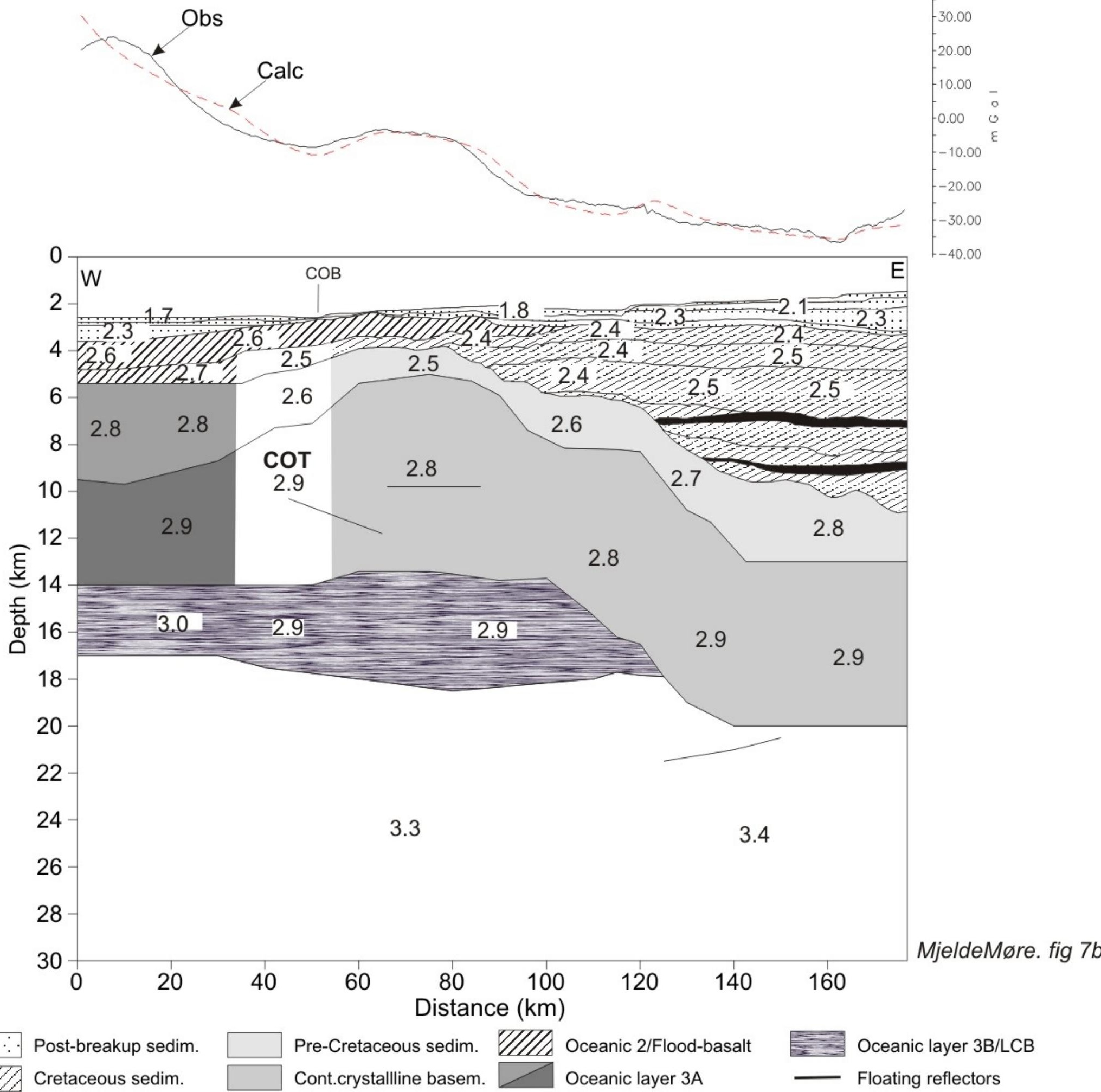




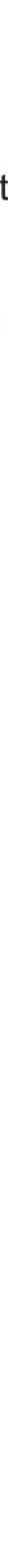

Post-breakup sedim.

Cretaceous sedim.
Pre-Cretaceous sedim.

Cont.crystallline basem.
Flood-basalt

CB
Floating reflectors

MjeldeMøre. fig 8a 


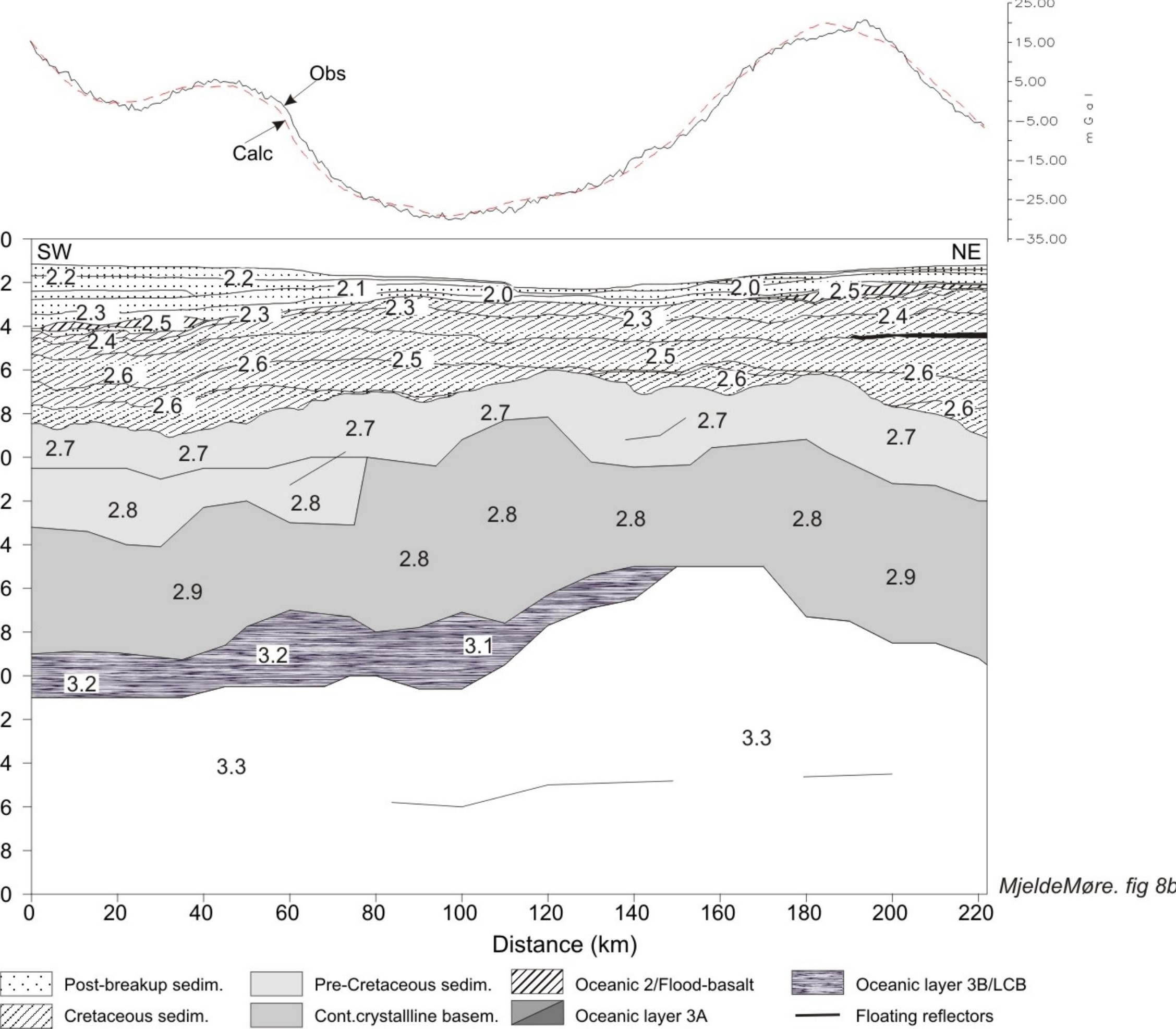




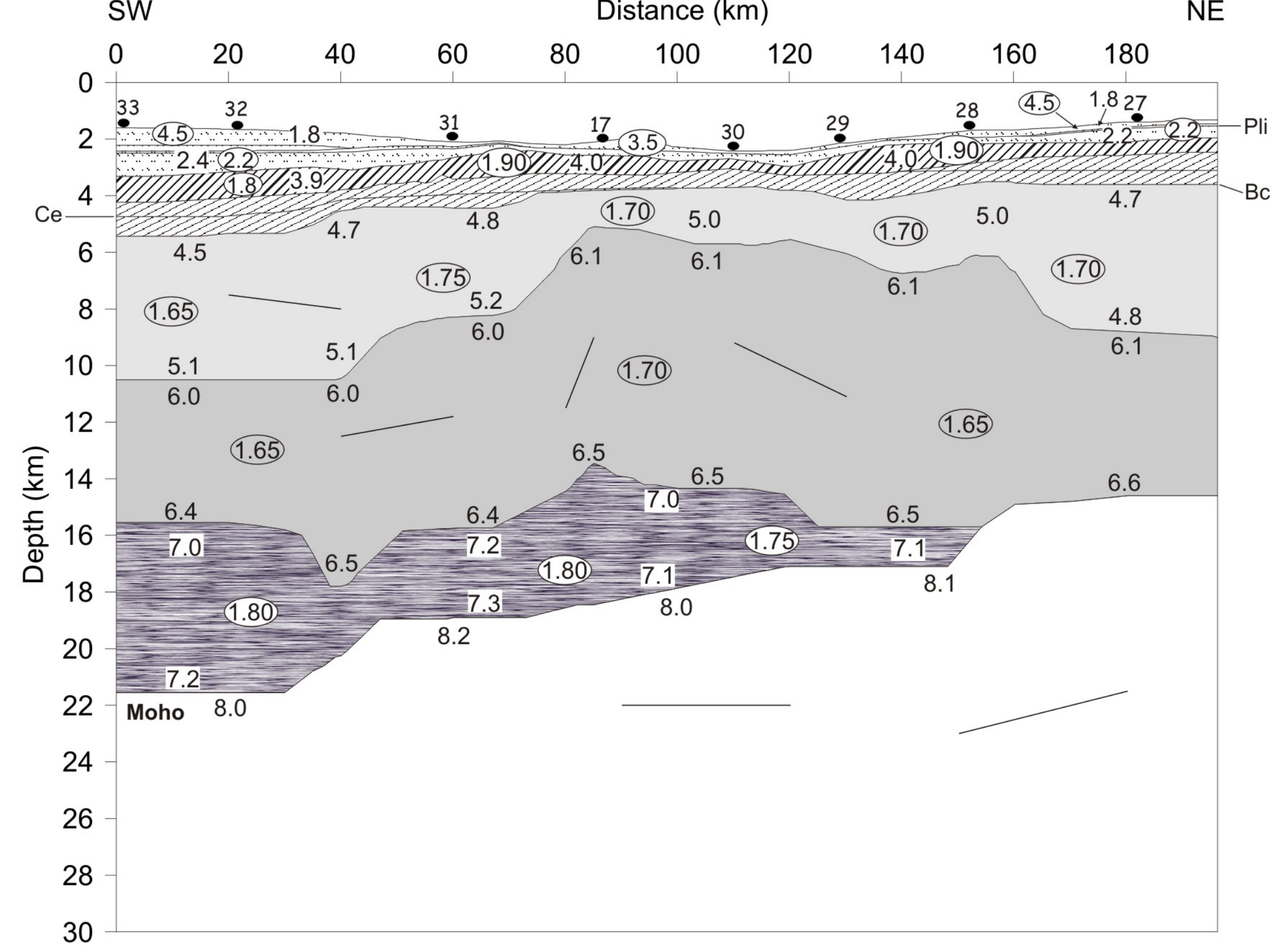

Post-breakup sedim. Pre-Cretaceous sedim. Flood-basalt Floating reflectors Cretaceous sedim. Cont.crystalline basem. 


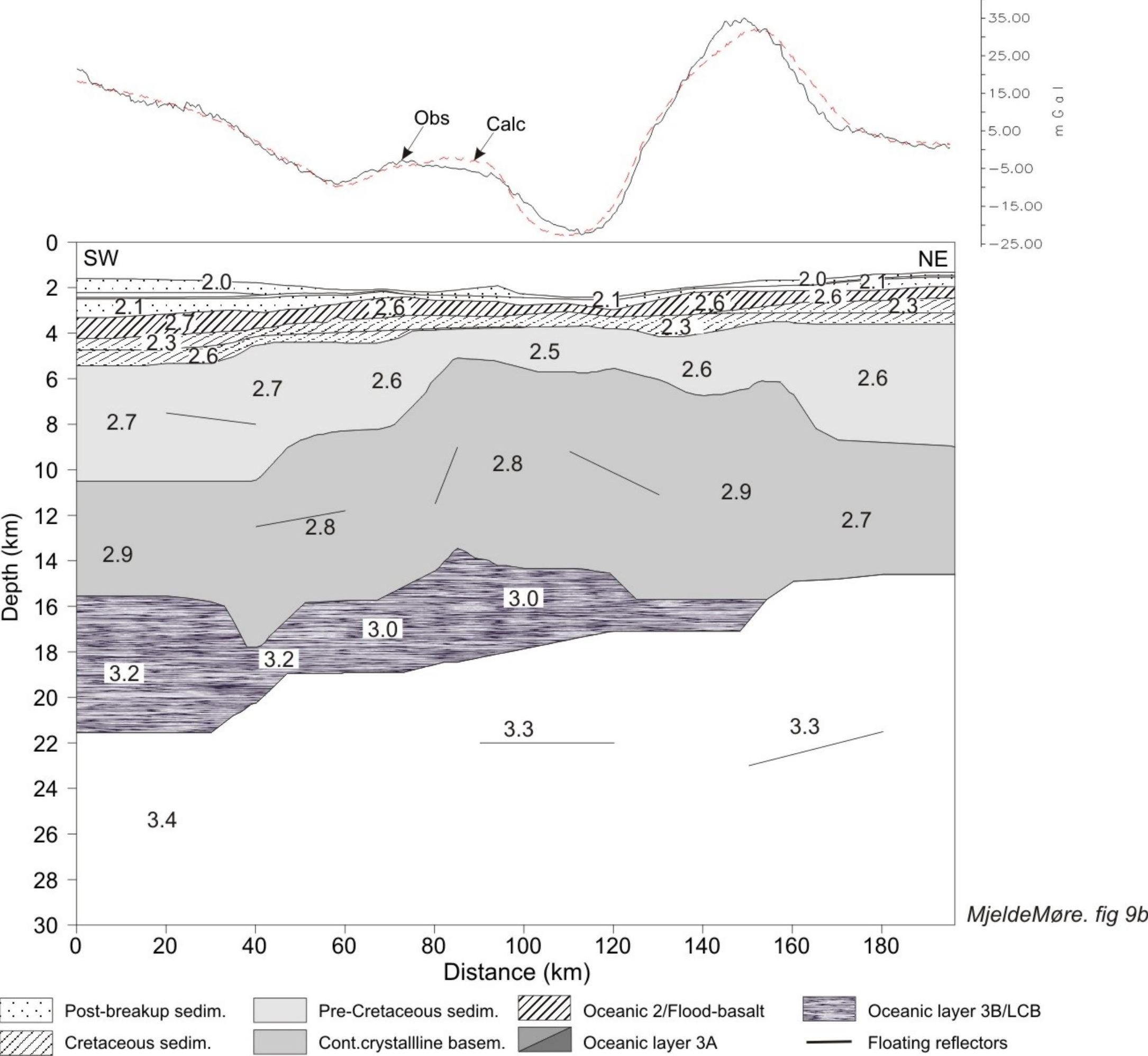




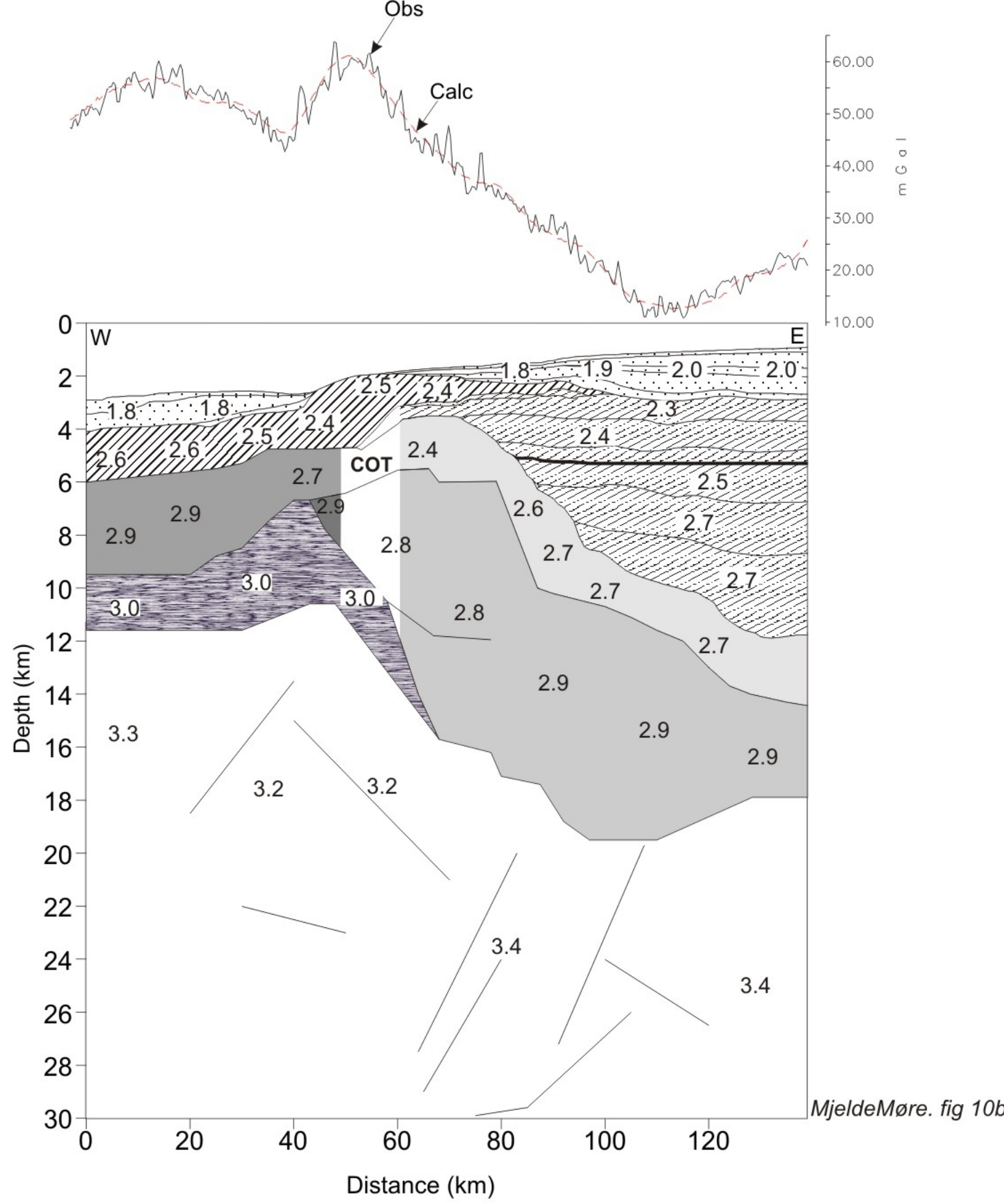

$\therefore \therefore$ Post-breakup sedim. Cretaceous sedim.
Pre-Cretaceous sedim. VIII/A Oceanic 2/Flood-basalt Cont.crystallline basem.
Oceanic layer 3B/LCB Floating reflectors 


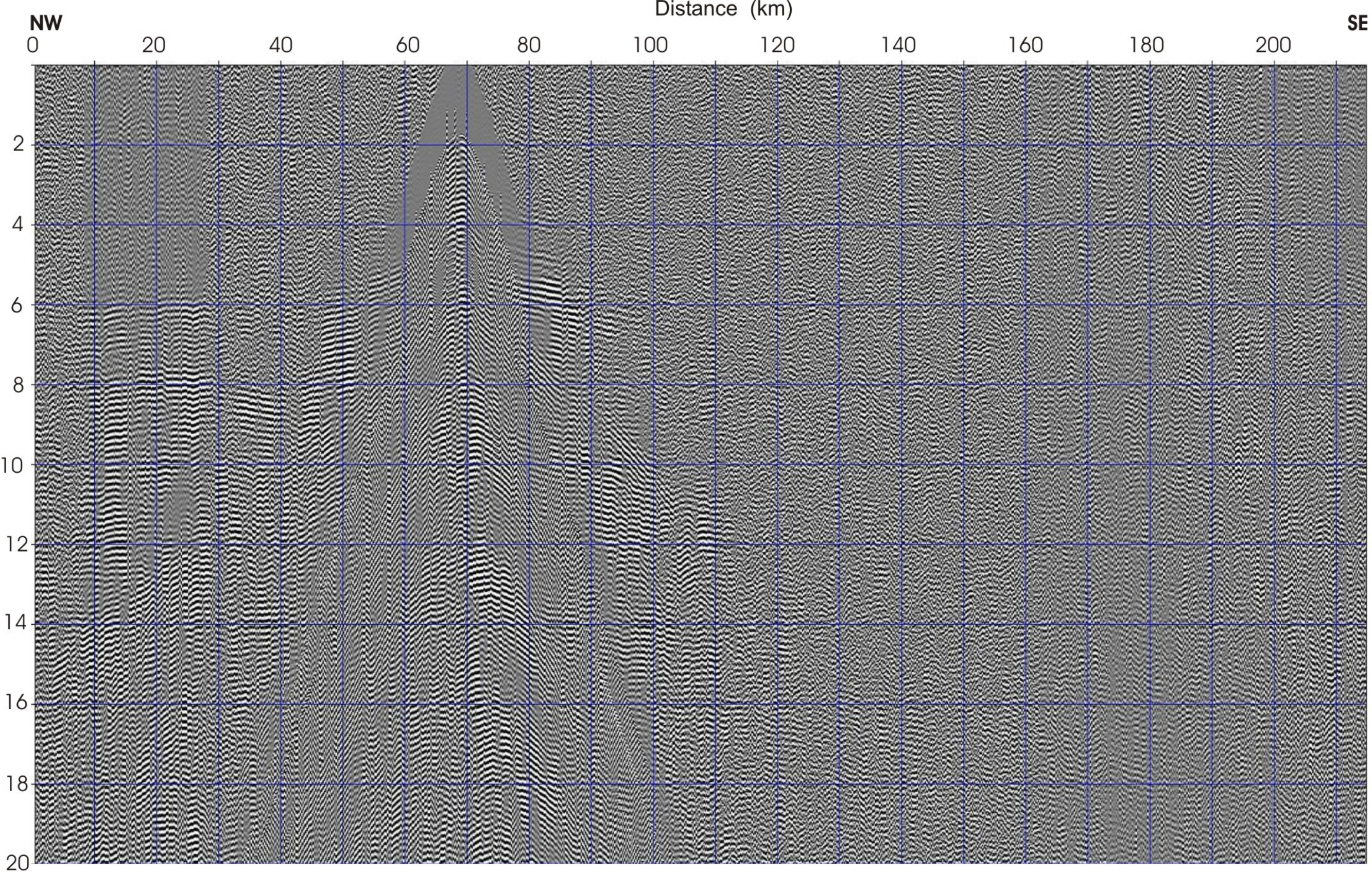

MjeldeMøre. fig 11a 
0

$20 \quad 40$

Distance $(\mathrm{km})$

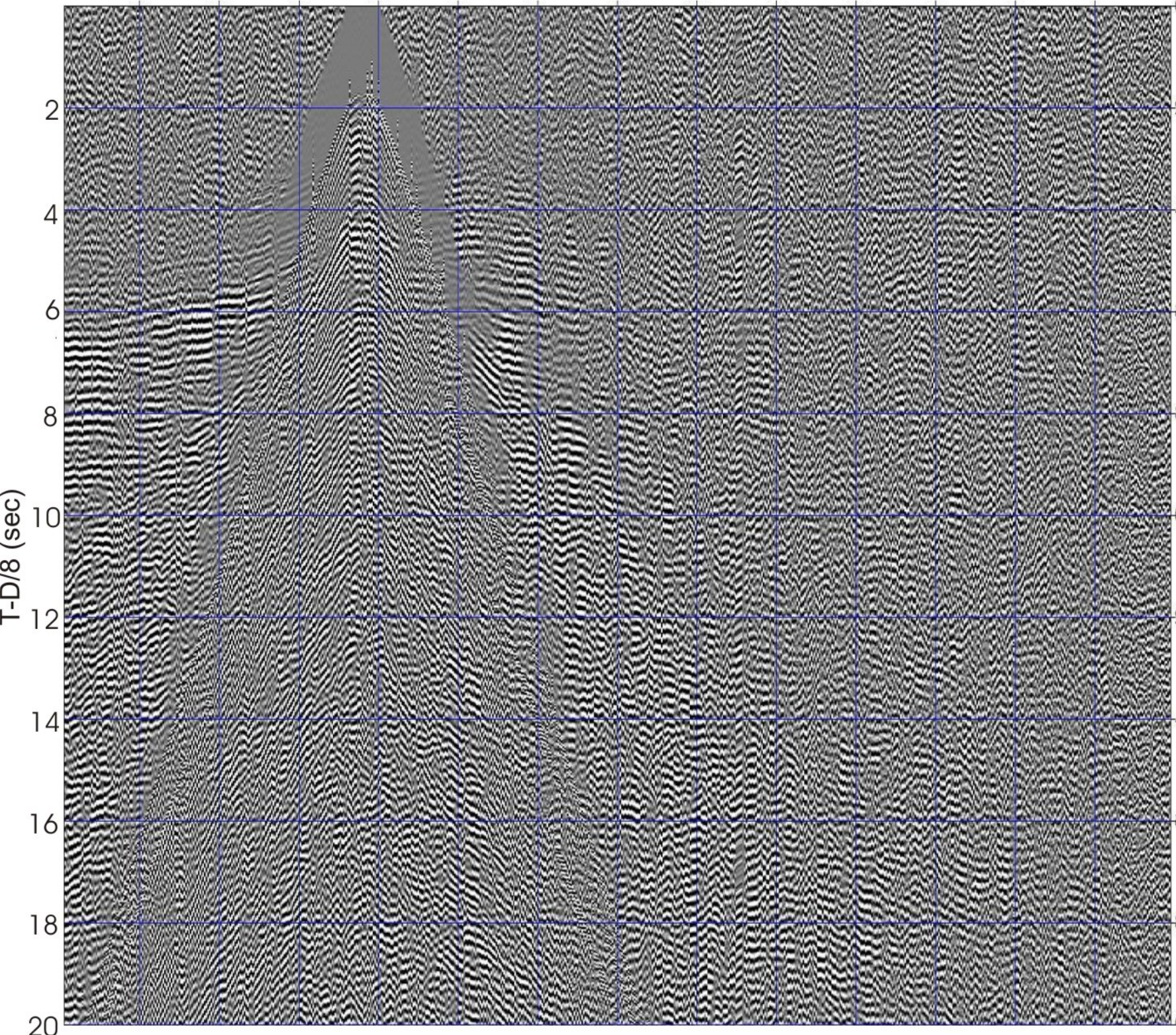

MjeldeMøre. fig 12a 

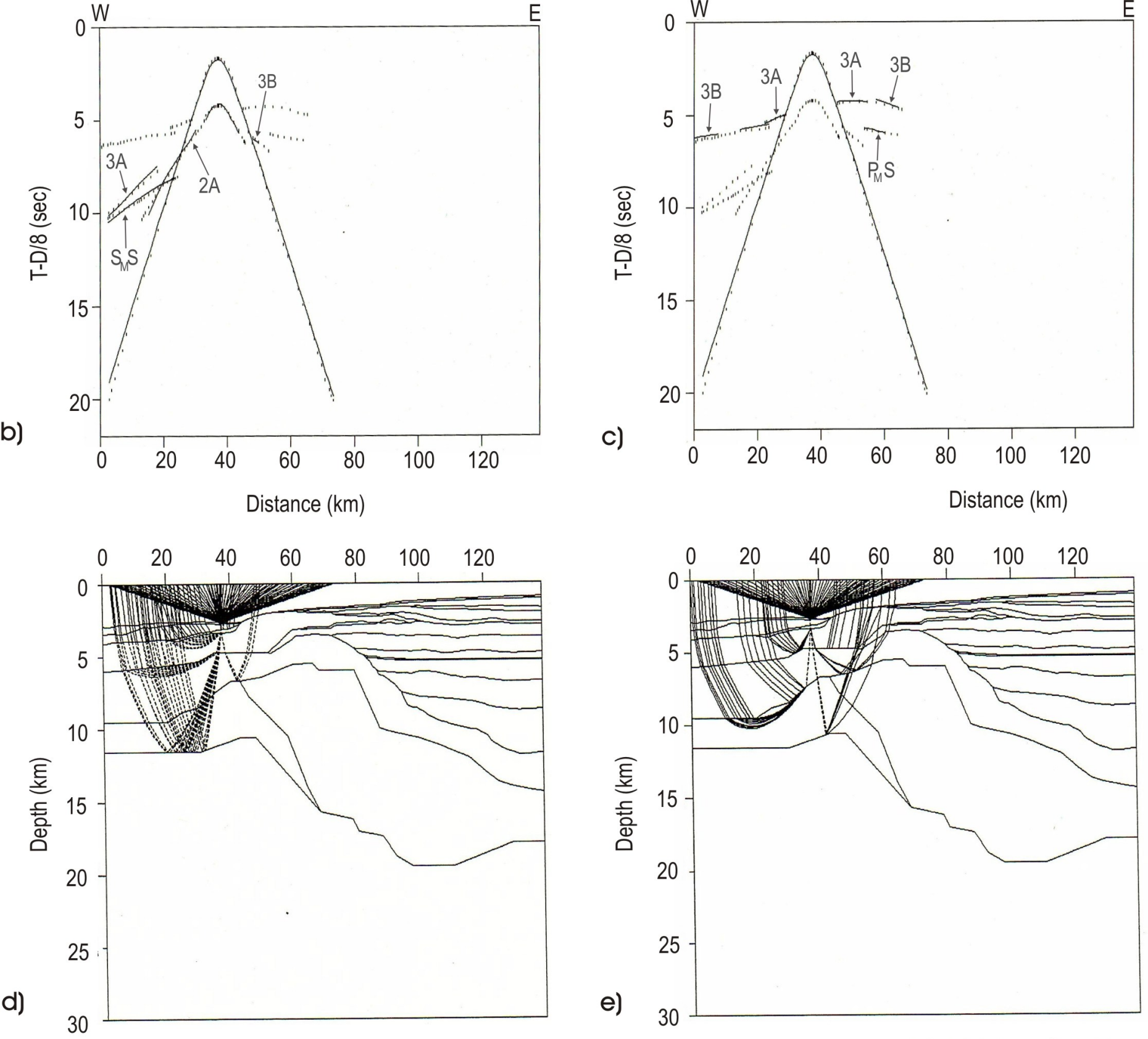

MjeldeMøre. fig 12b-e 
Layer number:

1: postopening sediments

2: basalt/innerflows

3:Cretaceous sediments

4:Pre-Cretaceous sediments
5:Crystalline basement

6:Lower crustal high-velocity layer

7:Oceanic crustal layer 3

8: Moho/Upper Mantle

\section{Average Chi-squared L1-5}

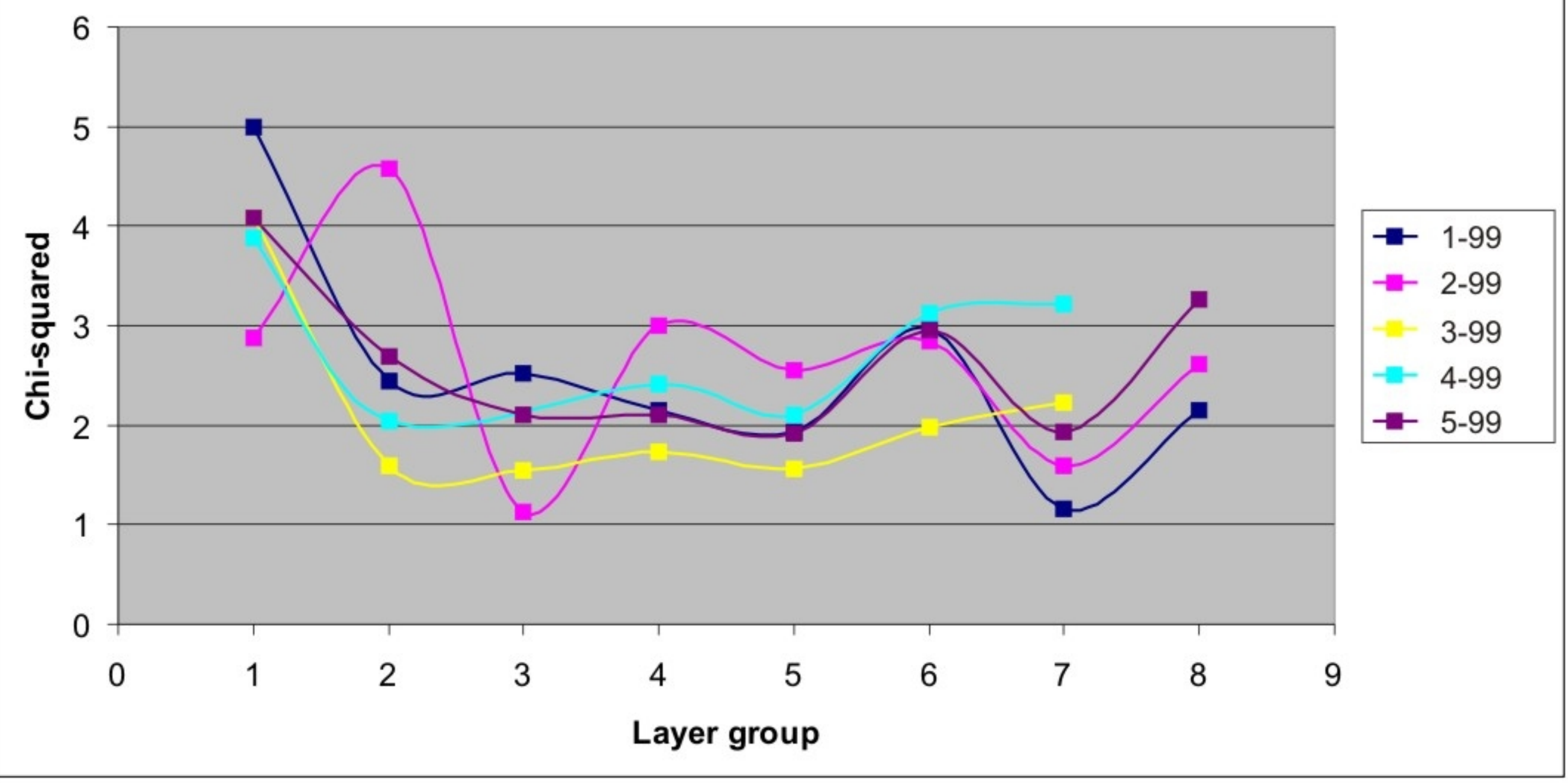



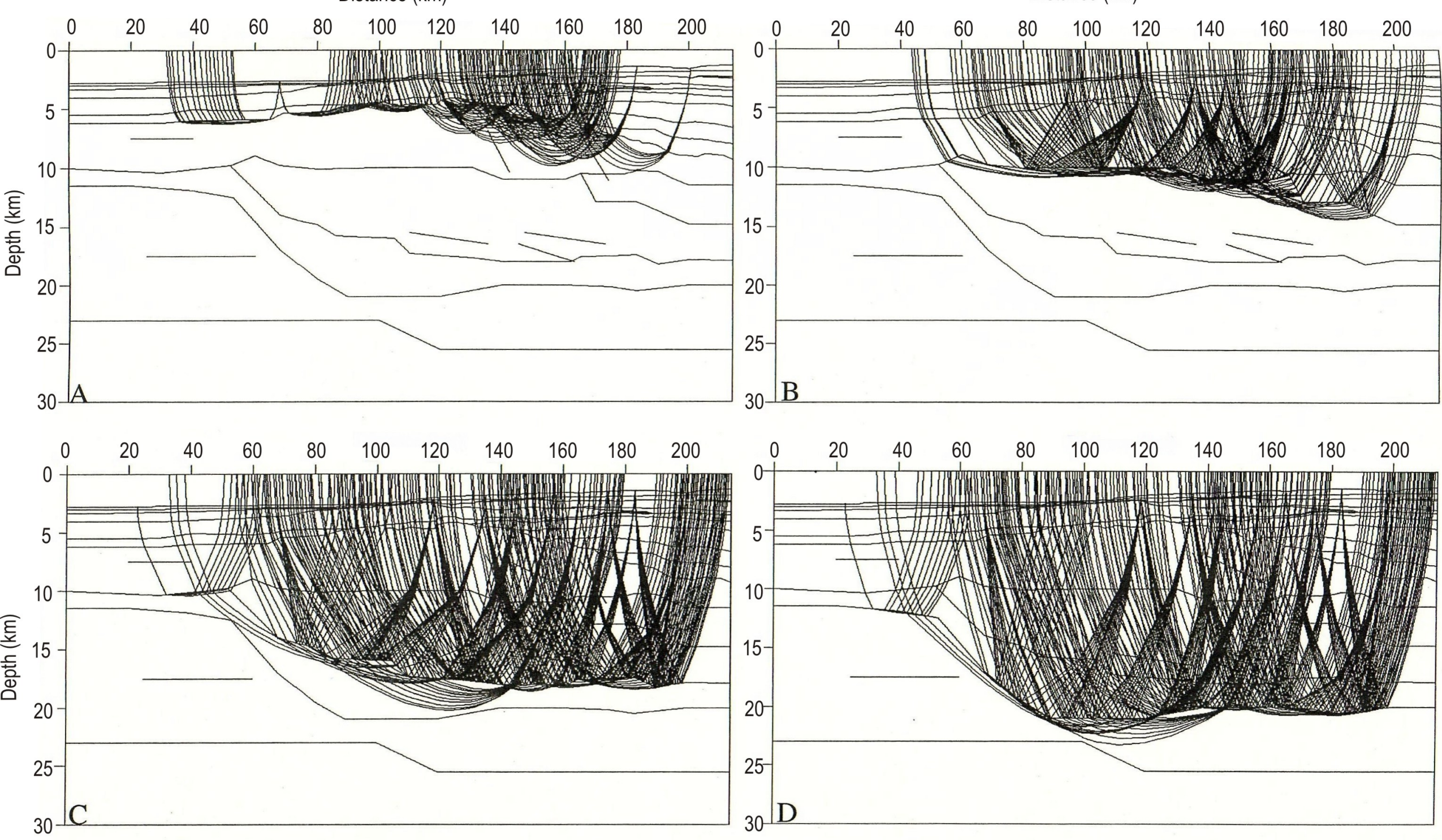

MjeldeMøre. fig 14a-d 

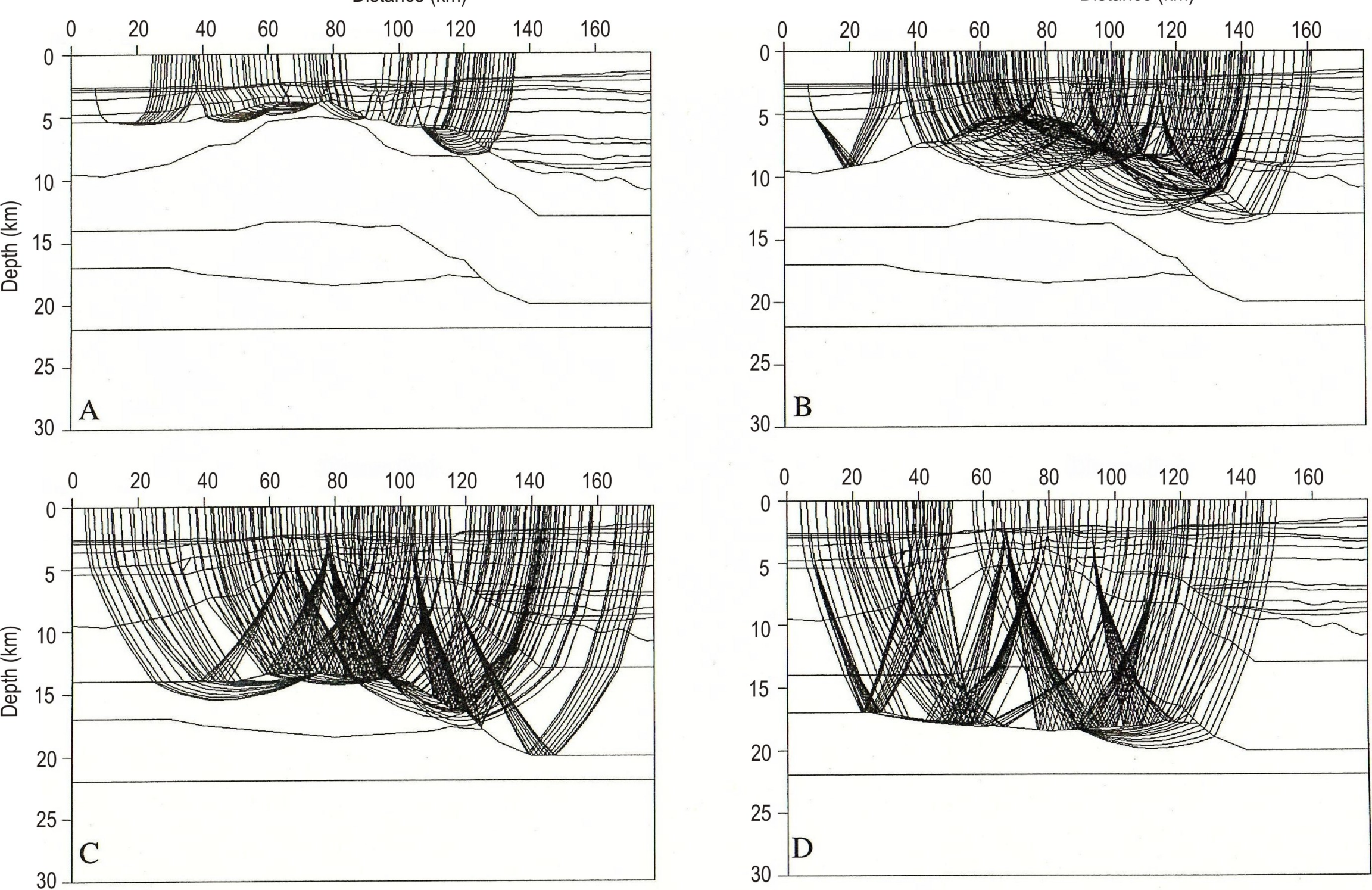

MjeldeMøre. fig 15a-d 

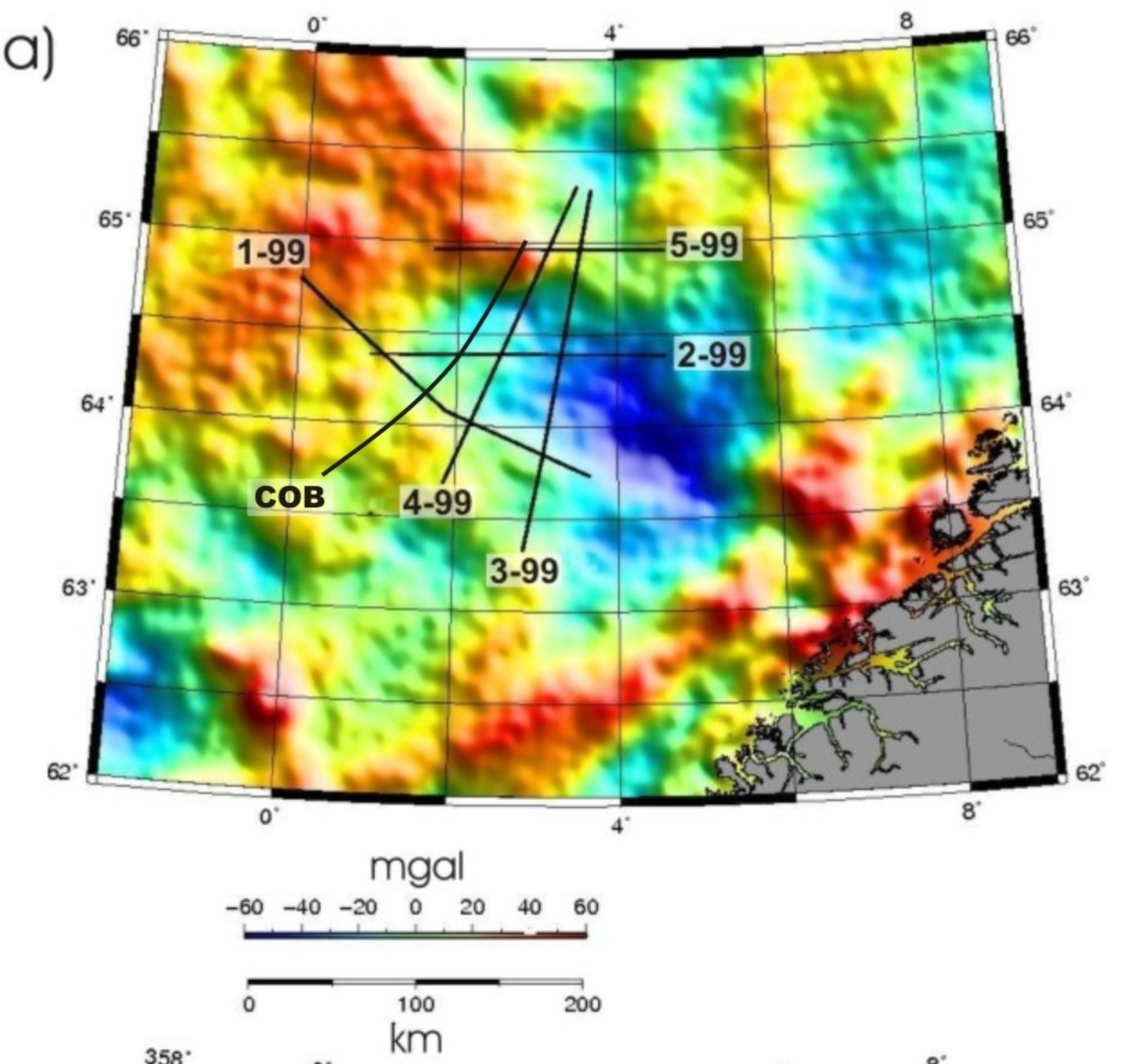

b)

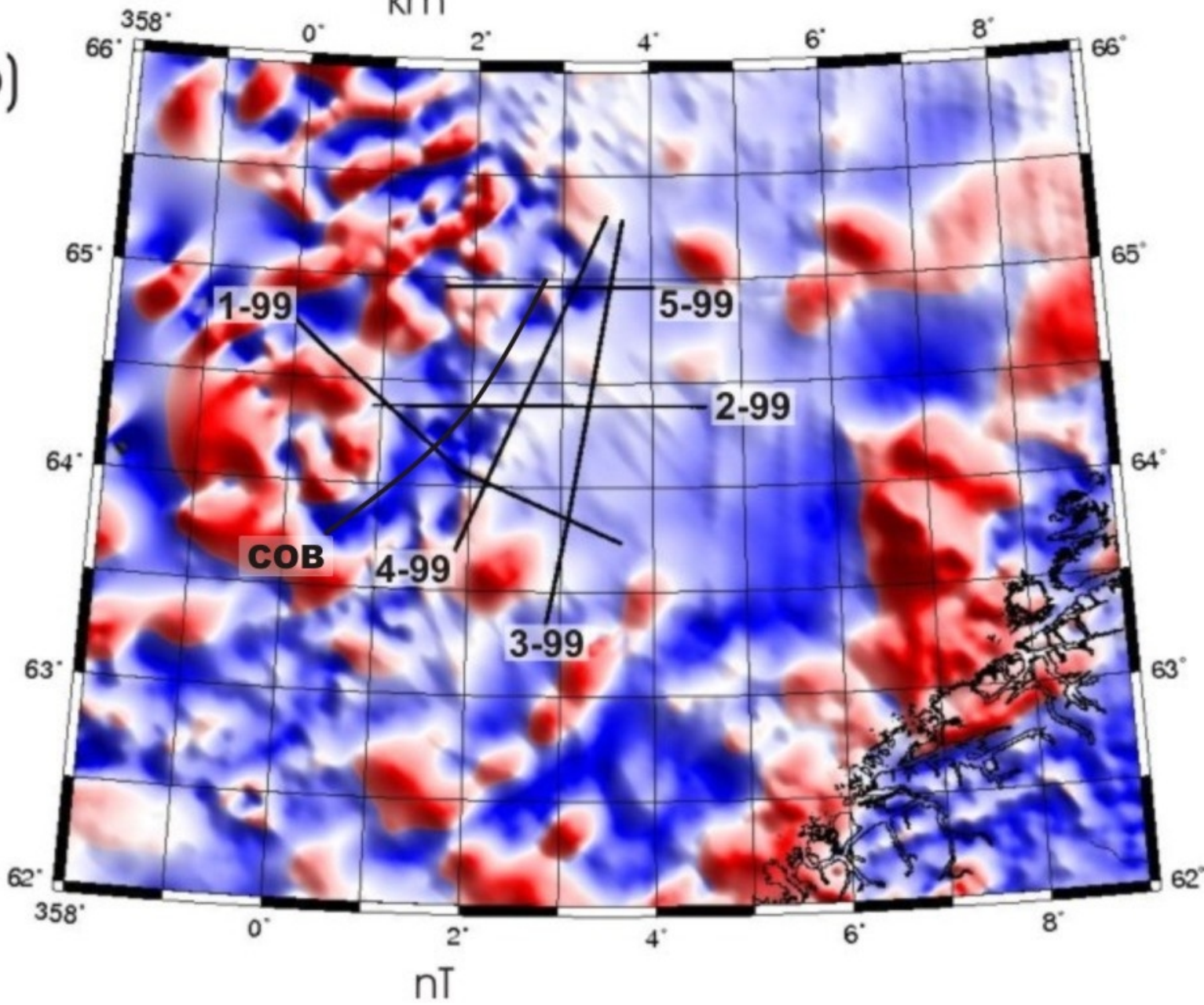




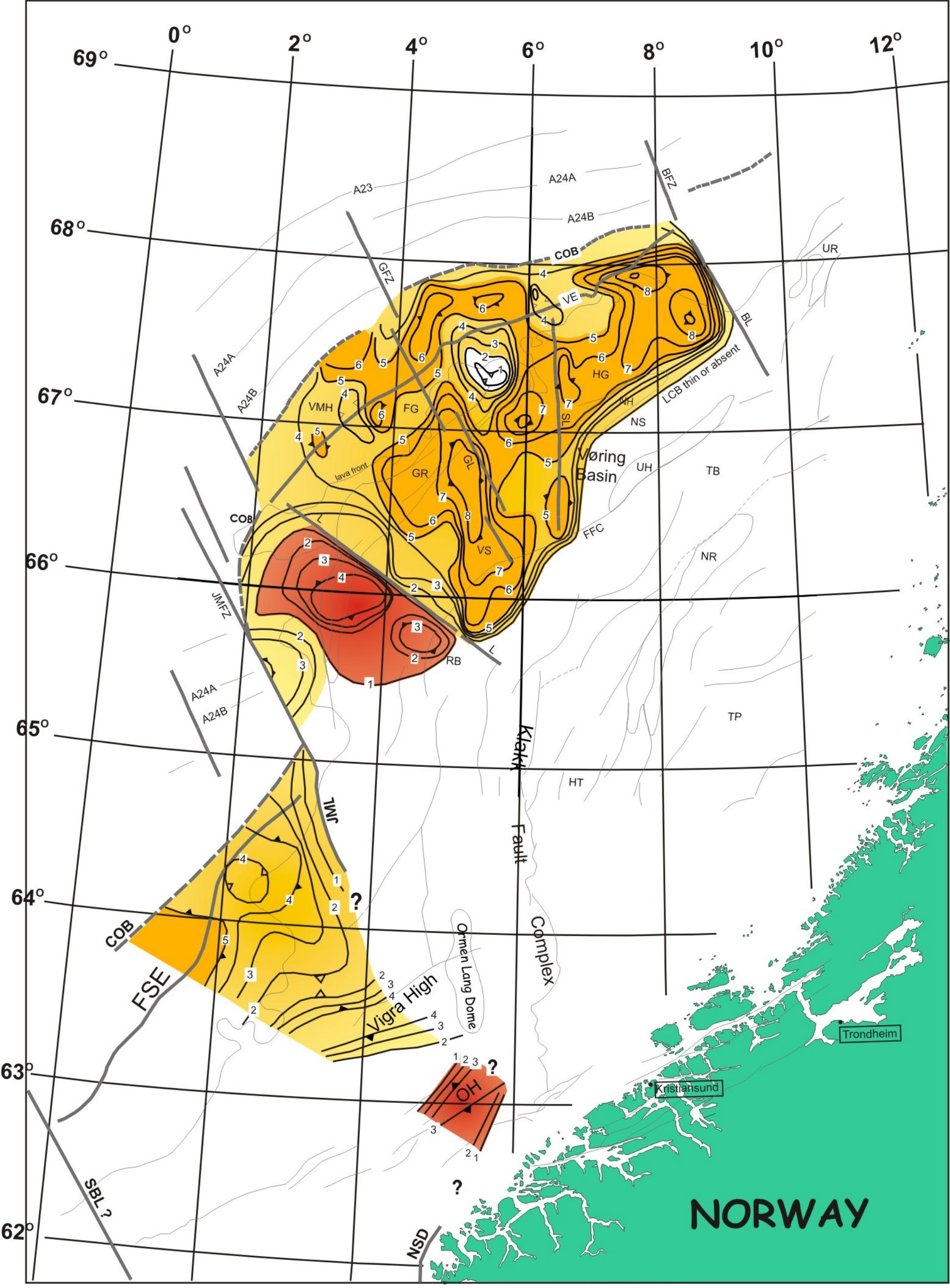

MjeldeMøre. fig 17 